\title{
Soil and Aquifer Salinization: Toward an Integrated Approach for Salinity Management of Groundwater
}

\author{
Richard Greene, Wendy Timms, Pichu Rengasamy, \\ Muhammad Arshad, and Richard Cresswell
}

\begin{abstract}
Degradation of the quality of groundwater due to salinization processes is one of the key issues limiting the global dependence on groundwater in aquifers. As the salinization of shallow aquifers is closely related to root-zone salinization, the two must be considered together. This chapter initially describes the physical and chemical processes causing salinization of the root-zone and shallow aquifers, highlighting the dynamics of these processes and how they can be influenced by irrigation and drainage practices, thus illustrating the connectivity between soil and groundwater salinization. The processes leading to aquifer salinization in both inland and coastal areas are discussed. The roles of extractive resource industries, such as mining and coal bed methane operations, in causing aquifer salinization are also outlined. Hydrogeochemical changes occurring during salinization of aquifers are examined with the aid of Piper and Mixing Diagrams. The chapter then illustrates the extent of the problem of groundwater salinization as influenced by management and policy using two case studies. The first is representative of a developing country and explores management of salt-affected soils in the Indus Valley, Pakistan, while the second looks at a developed country, and illustrates how through monitoring we can deduce
\end{abstract}

R. Greene $(\square) \cdot$ M. Arshad

Fenner School of Environment and Society, Australian National University, Canberra, ACT 0200, Australia

e-mail: Richard.greene@anu.edu.au

W. Timms

UNSW School of Mining Engineering, Kensington, NSW 2033, Australia

P. Rengasamy

School of Agriculture, Food and Wine, Adelaide University, PMB 1, Glen Osmond, SA 5064, Australia

R. Cresswell

Eco Logical Australia, Suite 1, Level 1, 101 Sussex Street, Sydney, NSW 2000, Australia 
causes of shallow aquifer salinity in the Namoi Catchment of NSW, Australia. Finally, there is a section on integration and conclusions where we illustrate how management to mitigate salinization needs to be integrated with policy to diminish the threat to productivity that occurs with groundwater degradation.

\subsection{Introduction}

Globally the increased dependence on groundwater to maintain societies and their economies is mediated by threats to supplies of groundwater from a range of environmental and economic pressures, including depletion of supplies (Chap. 2), degradation of the water quality (Chaps. 2 and 14) and the energy issues associated with groundwater extraction and usage (Chap. 4). The criticalities and potential impacts of poorly-managed water resources are nowhere more divisive than where the balance between surface water and groundwater fluxes are upset and excessive amounts of salt are concentrated at the surface and in the shallow sub-surface. This can be caused both by excessive use of water, infiltrating to recharge shallow aquifers that fill to the surface where evapotranspiration concentrates salts in the near-surface, or through inadequate supply of water which does not flush salts beyond the root zone, hence also salinizing the sub-surface. This chapter addresses the degradation of water quality as it relates to salinization of resources and in particular the environmental degradation that occurs as a result of salinization processes. This degradation from salinization can be due to a combination of natural and anthropogenic processes, but these can be closely related. Specifically, this chapter addresses salinization as it affects agricultural productivity and does not consider naturally saline lands, though the consequence of anthropogenic mistreatment of landscapes containing salt stores can result in a similar situation that can prove extremely difficult to rectify and may require timeframes that prohibit economic recovery.

A report by FAO in 2000 estimated that globally the area of salt-affected soils including saline and sodic soils was 831 million ha (Martinez-Beltran and Manzur 2005). It extended over all the continents including Africa, Asia, Australasia and the Americas. This salinization results from the accumulation of water soluble salts in the upper layers of the stratigraphy. It has a major impact on agricultural productivity, environmental health and economic welfare. These salt stores in the stratigraphy can also cause increases in the salinity of groundwater, as salts can be mobilised through irrigation, deep drainage and recharge events. Thus the salinization of surface soils and groundwater supplies are intimately related.

This chapter will first describe the physical and chemical processes causing salinization of the root-zone and shallow aquifers, highlighting the dynamics of these processes and how they can be influenced by irrigation and drainage practices and thus illustrate the connectivity between soil and groundwater salinization. Conceptual diagrams will be used to depict fluxes of water and salt between the different compartments of the integrated system. Two case studies will then illustrate the extent of the problem of groundwater salinization as influenced by 
management and policy. The first is representative of a developing country and explores management of salt-affected soils in the Indus Valley, Pakistan, while the second looks at a developed country, and illustrates how through monitoring we can deduce causes of shallow aquifer salinity in the Namoi Catchment of NSW. Finally, this chapter will show how management to mitigate salinization needs to be integrated with policy to diminish the threat to productivity and groundwater degradation.

\subsection{Major Types of Soil Salinity Based on Groundwater and Soil Processes}

Three major types of salinity may be identified globally, determined by relative interactions between soil and groundwater processes (Rengasamy 2006), as shown in Fig. 15.1. Thus, these types include:

1. Groundwater associated salinity (GAS) where fluctuations in shallow groundwater levels lead to salt discharge into root zone layers

2. Non-groundwater associated salinity (NAS) caused by poor leaching due to restricting hydraulic properties of some soil layers (also referred to as transient salinity), and

3. Irrigation associated salinity (IAS) which is due to the input of salts in the irrigation water and their accumulation in the root zone due to inadequate drainage.

\section{SALINE LAND}
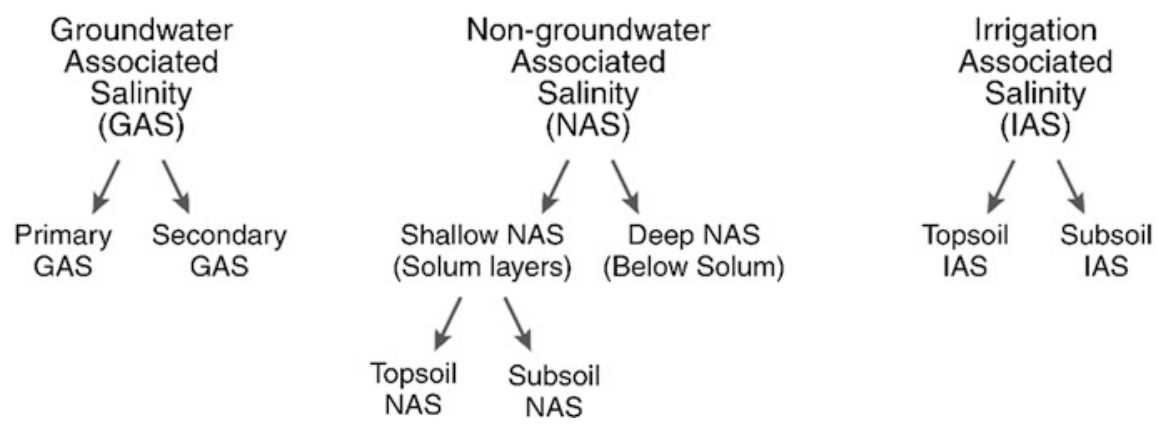

Fig. 15.1 Major types of salinity based on salinization processes 
Irrigation associated salinity may also arise from excessive leaching of applied water that causes a rise in water tables and subsequent salt discharge and thus presents as groundwater associated salinity.

\subsubsection{Groundwater Associated Salinity (GAS)}

Salt accumulation in soil layers occurs when the water tables are shallow, particularly when they are $<4 \mathrm{~m}$ from the surface and the salinity of groundwater becomes progressively higher due to evapotranspiration. Usually this situation occurs in foot slopes and valley floors of the landscape. Human activities, such as clearance of native deep-rooted perennial vegetation and subsequent agricultural practices, disturb the equilibrium levels of the water tables allowing increased recharge and salt movement from upper regolith layers that increases the salinity of the groundwater. Salts ultimately reach the surface via the discharge zone through capillary rise and high salinity levels in the soils can develop that are not conducive for agricultural production. Figure 15.2, for example, depicts an area of agricultural land in the Boorowa region of S.E. NSW badly affected by GAS.

\subsubsection{NAS and Transient Salinity}

Salt accumulation in root zone layers where water tables are deep, is termed transient salinity and generally salt concentrations fluctuate due to soil processes

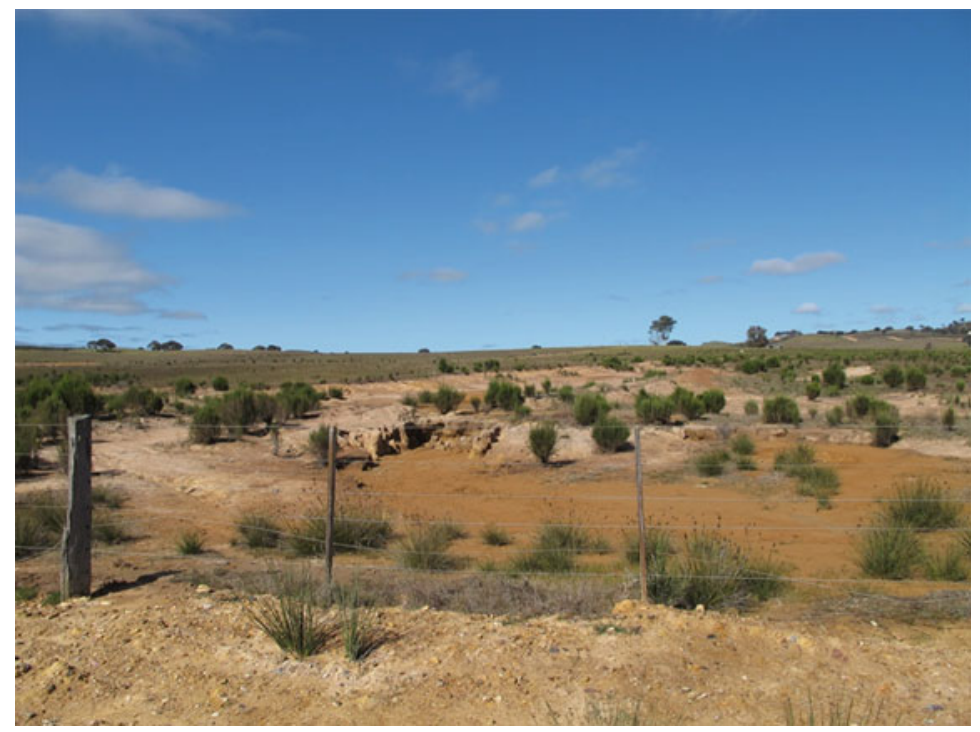

Fig. 15.2 Agricultural land in SE NSW badly affected by GAS 
and seasonal variability. Several sources of salts (as outlined in subsequent sections) contribute to the salts in the soil profile and these are concentrated due to evapotranspiration and the lack of sufficient leaching. The low hydraulic conductivity of many soil layers, which commonly occur in sodic subsoils, leads to poor drainage. Salt levels can be moderate to high and depend strongly on local soil and environmental conditions. Soil management and drainage options thus have to be specific for each site.

\subsubsection{Irrigation Induced Salinity}

The quality of irrigation water determines the amount and composition of salts which are stored in soil layers, while the relative hydraulic conductivity of the soil profile will determine the time taken for a specific area to salinize due to insufficient leaching. Irrigation management and drainage options are therefore also generally site specific.

\subsection{Physical and Chemical Processes Causing Salinization of Root Zone Layers and Aquifers}

While the processes of root zone and shallow aquifer salinization are inter-related, they have nevertheless traditionally been treated separately by agronomists and hydrogeologists, respectively. While attempts have been made to integrate our collective knowledge, the general disparity in ultimate drivers (agricultural productivity for agronomists and water supply for hydrogeologists) and scales of operation $(<2 \mathrm{~m}$ depth at paddock scale for the former and $>2 \mathrm{~m}$ depth and catchment scale for the latter) results in differing approaches; however these approaches ultimately converge where soil profiles and aquifers intersect. It is therefore instructive to approach salinization from these two directions to determine the intersection and synergies that exist.

\subsubsection{Soil Processes and Salt Accumulation in the Root Zone}

Accumulation of soluble salts above a certain level in the root zone of agricultural soils interferes with the crop production by either directly affecting the physiological functions of the plants and/or indirectly by disturbing soil physical and chemical conditions. The commonly used terms 'Primary' and 'Secondary' salinity are based on whether salt accumulates by natural phenomena or as a consequence of mismanagement of natural resources (viz. soil and water). There are several sources of salts causing soil salinization including natural weathering of soil minerals, salts added through precipitation (e.g. Blackburn and McLeod 1983) and salts associated with aeolian dust (e.g. Shiga et al. 2011). Other natural salinization processes 
include discharge of naturally saline groundwaters and saline groundwater intrusion. Agronomic practices such as fertiliser and pesticide application will also add salts to the soils, as will irrigation and dumping of waste materials. In addition to requiring a source of salts, climatic, hydrological and landscape features, combined with human activities and plant interactions, determine the specific location of salinization in the root zone and also the quantity and quality of salts accumulating.

\subsubsection{Salinization of the Root-Zone}

Figure 15.3 illustrates typical processes leading to salt accumulation in the root zone of a sodic soil, including the specific case of development of transient salinity (Fig. 15.3b). These salt stores in the root zone can have major effects on plants growth and soil processes (Fig. 15.3a) and can also affect groundwater supplies deeper in the landscape if recharge conditions change and a net downward flux of water and hence salt occurs.

\subsubsection{Effects on Plant Growth}

Irrespective of how the salts have accumulated in soil layers, the concentrations of soluble salts affect plant growth through the osmotic and ionic effects (Munns and Tester 2008). Thus, as salinity increases, the osmotic potential required to extract water into plant cells decreases and inhibits the water uptake by plants (water always moving from a higher to lower potential energy level). Increasing salinity
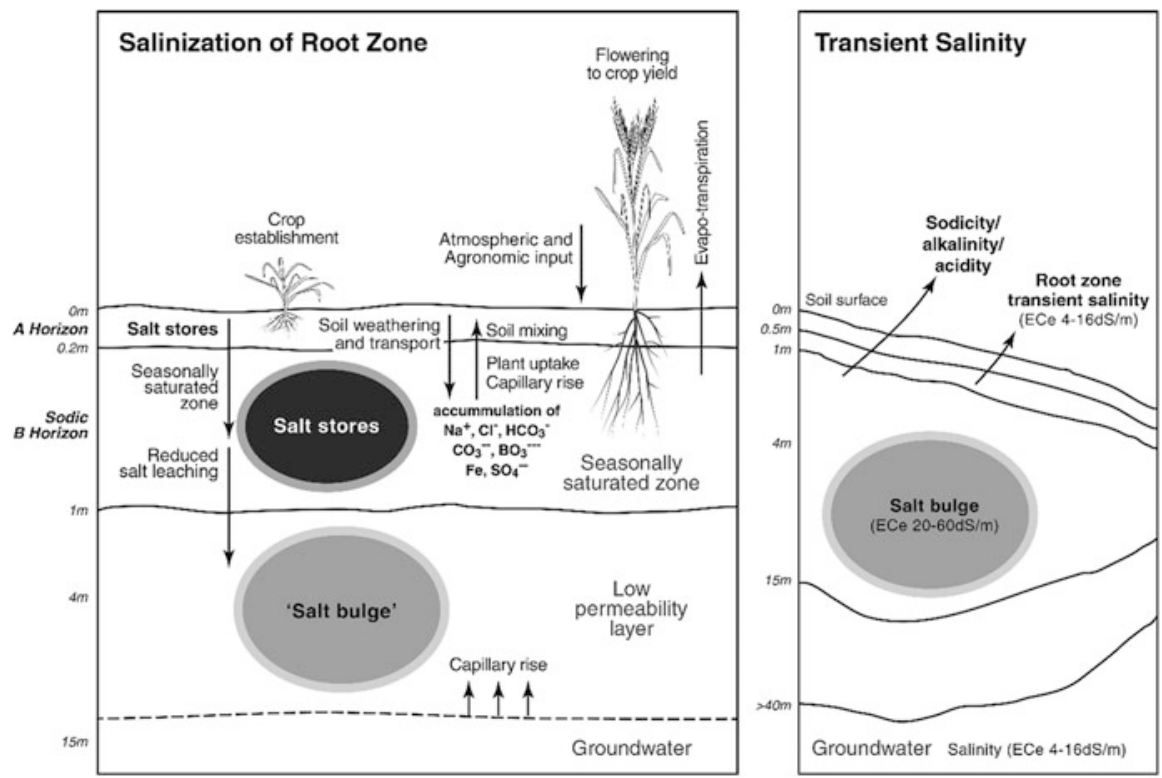

Fig. 15.3 (a) Salt accumulation in the root zone and effects on plant growth and soil processes. (b) Development of transient salinity (After Rengasamy 2006) 
also leads to accumulation of ions in the plant over a period of time and leads to ion toxicity or ion imbalance.

\subsubsection{Effects on Soil Processes}

Salts can also affect many soil processes, such as soil water dynamics, soil structural stability, and solubility of plant nutrients under different hydrogen ion concentrations $(\mathrm{pH})$ and electron conditions ( $\mathrm{Eh}$, or redox) of the soil water. Different categories of salt affected soils can therefore be distinguished based on the ionic composition of soil solution, each affecting soil properties and the mechanism of plant growth in different ways (Table 15.1).

\subsubsection{Effect of Cations and Anions on Soil Structure}

It has been well established that when the amount of soil adsorbed sodium ions, commonly measured as exchangeable sodium percentage (ESP) in soils (or estimated through the sodium adsorption ratio (SAR) of the soil solution), increases above a critical value (ESP $>6$ in Australia and ESP $>15$ in USA and other countries), and the EC of the soil solution decreases below a critical threshold value, the soil structure deteriorates severely due to dispersion of the clay microaggregates or quasi-crystals (Greene et al. 1973; Quirk and Schofield 1955; Rengasamy et al. 1984). With clay dispersion and concomitant blockage of the soil pores, permeability is reduced; this effect is particularly pronounced in smectite dominant clay soils (Turner et al. 2008). As a consequence water and air movement and water storage are highly restricted thereby affecting root environments and, consequently, plant growth (Rengasamy 2013). SAR is readily determined from the major cation composition of soil water and hence used as an indicator of sodium effects on soils.

$$
\mathrm{SAR}=\mathrm{Na}^{+} /\left(\mathrm{Ca}^{2+}+\mathrm{Mg}^{2+}\right)^{0.5}
$$

where the concentrations of $\mathrm{Na}^{+}, \mathrm{Ca}^{2+}$ and $\mathrm{Mg}^{2+}$ in soil solutions are expressed as mmol.L ${ }^{-1}$.

SAR, however, has a number of limitations which distil its effectiveness in predicting soil effects. Potassium $\left(\mathrm{K}^{+}\right)$ions, for example, are not considered in this SAR model, even though adsorbed potassium has been found to affect soil structure (Rengasamy and Sumner 1998). This is partly because $\mathrm{K}^{+}$has traditionally been hard to quantitatively measure and fortunately has been found to occur at relatively low concentrations $(<5 \%)$ in most waters. Recently, Marchuk and Rengasamy (2011) derived ionicity indices of clay-cation bonding and showed that the dispersive effects (which causes soil structural problems) of $\mathrm{Na}^{+}$and $\mathrm{K}^{+}$, and the flocculating effects (which promote soil structural integrity) are highly related to ionicity, or covalency, of the clay-cation bondings.

Further, the effects of $\mathrm{Ca}^{2+}$ and $\mathrm{Mg}^{2+}$ in reducing monovalent adsorption are considered to be equal in the SAR equation. However, Rengasamy and Sumner 
Table 15.1 Categories of salt-affected soils based on $\mathrm{EC}_{\mathrm{e}}(\mathrm{dS} / \mathrm{m}), \mathrm{SAR}_{\mathrm{e}}$ and $\mathrm{pH}_{1: 5}$ of soil solutions and possible mechanisms of impact on plants. Toxicity, deficiency or ion-imbalance due to various ions will depend on the ionic composition of soil solution

\begin{tabular}{|c|c|c|c|}
\hline No. & $\begin{array}{l}\text { Category of } \\
\text { saline soil }\end{array}$ & Criteria & Possible mechanisms of impact on plants \\
\hline 1 & $\begin{array}{l}\text { Acidic-saline } \\
\text { soil }\end{array}$ & $\begin{array}{l}\mathrm{EC}_{\mathrm{e}}>4 \\
\mathrm{SAR}_{\mathrm{e}}<6 \\
\mathrm{pH}<6\end{array}$ & $\begin{array}{l}\text { Osmotic effect; microelement }(\mathrm{Fe}, \mathrm{Al}, \mathrm{Mn} \text { etc. }) \\
\text { toxicity; } \mathrm{SO}_{4}{ }^{2-} \text { toxicity in very low } \mathrm{pH}\end{array}$ \\
\hline 2 & $\begin{array}{l}\text { Neutral saline } \\
\text { soil }\end{array}$ & $\begin{array}{l}\mathrm{EC}_{\mathrm{e}}>4 \\
\mathrm{SAR}_{\mathrm{e}}<6 \\
\mathrm{pH} 6-8\end{array}$ & $\begin{array}{l}\text { Osmotic effect; toxicity of dominant anion or } \\
\text { cation other than } \mathrm{Na}^{+}\end{array}$ \\
\hline 3 & $\begin{array}{l}\text { Alkaline-saline } \\
\text { soil }\end{array}$ & $\begin{array}{l}\mathrm{EC}_{\mathrm{e}}>4 \\
\mathrm{SAR}_{\mathrm{e}}<6 \\
\mathrm{pH} 8-9\end{array}$ & Osmotic effect; $\mathrm{HCO}_{3}{ }^{-}$and $\mathrm{CO}_{3}{ }^{2-}$ toxicity; \\
\hline 4 & $\begin{array}{l}\text { Highly alkaline- } \\
\text { saline soil }\end{array}$ & $\begin{array}{l}\mathrm{EC}_{\mathrm{e}}>4 \\
\mathrm{SAR}_{\mathrm{e}}<6 \\
\mathrm{pH}>9\end{array}$ & $\begin{array}{l}\text { Osmotic effect; } \mathrm{HCO}_{3}{ }^{-} \text {and } \mathrm{CO}_{3}{ }^{2-} \text { toxicity; } \\
\text { microelement ( } \mathrm{Fe}, \mathrm{Al}, \mathrm{Mn} \text { etc.) toxicity }\end{array}$ \\
\hline 5 & $\begin{array}{l}\text { Acidic-saline- } \\
\text { sodic soil }\end{array}$ & $\begin{array}{l}\mathrm{EC}_{\mathrm{e}}>4 \\
\mathrm{SAR}_{\mathrm{e}}>6 \\
\mathrm{pH}<6\end{array}$ & $\begin{array}{l}\text { Osmotic effect; } \mathrm{Na}^{+} \text {and microelement }(\mathrm{Fe}, \mathrm{Al}, \mathrm{Mn} \\
\text { etc.) toxicity }\end{array}$ \\
\hline 6 & $\begin{array}{l}\text { Neutral saline- } \\
\text { sodic soil }\end{array}$ & $\begin{array}{l}\mathrm{EC}_{\mathrm{e}}>4 \\
\mathrm{SAR}_{\mathrm{e}}>6 \\
\mathrm{pH} 6-8\end{array}$ & $\begin{array}{l}\text { Osmotic effect; } \mathrm{Na}^{+} \text {toxicity; toxicity of dominant } \\
\text { anion }\left(\mathrm{Cl}^{-} \text {or } \mathrm{SO}_{4}{ }^{2-}\right)\end{array}$ \\
\hline 7 & $\begin{array}{l}\text { Alkaline-saline- } \\
\text { sodic soil }\end{array}$ & $\begin{array}{l}\mathrm{EC}_{\mathrm{e}}>4 \\
\mathrm{SAR}_{\mathrm{e}}>6 \\
\mathrm{pH} 8-9\end{array}$ & $\begin{array}{l}\text { Osmotic effect; } \mathrm{Na}^{+} \text {toxicity; } \mathrm{HCO}^{-} \text {and } \mathrm{CO}_{3}{ }^{2-} \\
\text { toxicity }\end{array}$ \\
\hline 8 & $\begin{array}{l}\text { Highly alkaline- } \\
\text { saline-sodic soil }\end{array}$ & $\begin{array}{l}\mathrm{EC}_{\mathrm{e}}>4 \\
\mathrm{SAR}_{\mathrm{e}}>6 \\
\mathrm{pH}>9\end{array}$ & $\begin{array}{l}\text { Osmotic effect; } \mathrm{Na}^{+} \text {toxicity; } \mathrm{HCO}^{-} \text {and } \mathrm{CO}_{3}{ }^{2-} \\
\text { toxicity; microelement }(\mathrm{Fe}, \mathrm{Al}, \mathrm{Mn} \text { etc.) toxicity }\end{array}$ \\
\hline 9 & $\begin{array}{l}\text { Acidic-sodic } \\
\text { soil }\end{array}$ & $\begin{array}{l}\mathrm{EC}_{\mathrm{e}}<4 \\
\mathrm{SAR}_{\mathrm{e}}>6 \\
\mathrm{pH}<6\end{array}$ & $\begin{array}{l}\text { Indirect effect due to soil structural problems; } \\
\text { seasonal waterlogging can induce microelement } \\
\text { (Fe, } \mathrm{Al}, \mathrm{Mn} \text { etc.) toxicity }\end{array}$ \\
\hline 10 & $\begin{array}{l}\text { Neutral sodic } \\
\text { soil }\end{array}$ & $\begin{array}{l}\mathrm{EC}_{\mathrm{e}}<4 \\
\mathrm{SAR}_{\mathrm{e}}>6 \\
\mathrm{pH} 6-8\end{array}$ & $\begin{array}{l}\text { Indirect effect due to soil structural problems; } \\
\text { seasonal waterlogging; } \mathrm{Na}^{+} \text {toxicity at high } \mathrm{SAR}_{\mathrm{e}}\end{array}$ \\
\hline 11 & $\begin{array}{l}\text { Alkaline-sodic } \\
\text { soil }\end{array}$ & $\begin{array}{l}\mathrm{EC}_{\mathrm{e}}<4 \\
\mathrm{SAR}_{\mathrm{e}}>6 \\
\mathrm{pH} 8-9\end{array}$ & $\begin{array}{l}\text { Indirect effect due to soil structural problems; } \\
\text { seasonal waterlogging; } \mathrm{Na}^{+} \text {toxicity at high } \mathrm{SAR}_{\mathrm{e}} \text {; } \\
\mathrm{HCO}_{3}{ }^{-} \text {and } \mathrm{CO}_{3}{ }^{2-} \text { toxicity }\end{array}$ \\
\hline 12 & $\begin{array}{l}\text { Highly alkaline- } \\
\text { sodic soil }\end{array}$ & $\begin{array}{l}\mathrm{EC}_{\mathrm{e}}<4 \\
\mathrm{SAR}_{\mathrm{e}}>6 \\
\mathrm{pH}>9\end{array}$ & $\begin{array}{l}\text { Indirect effect due to soil structural problems; } \\
\text { seasonal waterlogging; } \mathrm{Na}^{+} \text {toxicity at high } \mathrm{SAR}_{\mathrm{e}} \text {; } \\
\mathrm{HCO}_{3}{ }^{-} \text {and } \mathrm{CO}_{3}{ }^{2-} \text { toxicity; microelement }(\mathrm{Fe}, \mathrm{Al} \text {, } \\
\text { Mn etc.) toxicity }\end{array}$ \\
\hline
\end{tabular}

(1998) showed the flocculation efficiency of $\mathrm{Mg}$ is actually about 0.6 times that of $\mathrm{Ca}$.

Based on these recent discoveries, Rengasamy and Marchuk (2011) proposed an alternative "cation ratio of soil structural stability" (CROSS) to replace SAR. CROSS incorporates the differential effects of $\mathrm{Na}^{+}$and $\mathrm{K}^{+}$in dispersing soil 
clays, and also the differential effects of $\mathrm{Ca}^{2+}$ and $\mathrm{Mg}^{2+}$ in flocculating soil clays. CROSS is defined as:

$$
\text { CROSS }=\left(\mathrm{Na}^{+}+0.56 \mathrm{~K}^{+}\right) /\left(\mathrm{Ca}^{2+}+0.6 \mathrm{Mg}^{2+}\right)^{0.5}
$$

where the cation concentrations are expressed in mmol.L $\mathrm{L}^{-1}$.

CROSS estimated in soil solutions can be used as a better indicator of potential soil structural effects when compared to SAR (Marchuk and Rengasamy 2012; Marchuk et al. 2013). The actual effects on soil structure depend on the total electrolyte concentration, generally measured as electrical conductivity (EC). When the ionic strength, or EC, of the soil solution is below a critical threshold level (see Table 15.1), the cationic effects on soil structure are predominant.

Anions, even in low ionic strength solutions, critically contribute to the $\mathrm{pH}$ of the soil solution. This alters the net charge on soils and thereby affects the influence of cations. Thus, sulphates and chlorides tend to contribute to acidic $\mathrm{pH}$ levels while bicarbonate and carbonate ions generally promote alkaline conditions. Notably, the dispersive effects of $\mathrm{Na}^{+}$and $\mathrm{K}^{+}$are enhanced when the soil $\mathrm{pH}$ is above 8.5 (Marchuk et al. 2013).

\subsubsection{Management of Salt-Affected Soils}

Sustainable agriculture in salt-affected soils, whether in dryland or irrigated regions, will depend on maintaining low levels of salinity as well as maintaining the proper balance of cations and anions. Accurate, spatially explicit data on soil water chemistry is vital and consideration of the potential effects of differing sources and expressions of salinity is required to make informed assessment of appropriate remediation strategies. While application of fresher waters may serve to dilute salt-affected lands, if the inherent conditions are highly sodic, or have high acidity, or alkalinity, then reduction in salinity alone my result in further degradation of soil condition (Turner et al. 2008) (Table 15.1).

\subsubsection{Processes Leading to Salinization of Aquifers}

\subsubsection{Aquifer Salinization in Inland Areas}

Foster and Chilton (2003) have summarised decades of investigations into salinization of aquifers and consolidated several processes leading to salinization of aquifers in inland areas (Fig. 15.4). These processes include: (i) rising groundwater tables due to inefficient surface irrigation and inadequate drainage, (ii) natural salinity mobilized from the landscape due to land clearing of native vegetation, and (iii) disturbance of natural groundwater salinity stratification by well construction and groundwater extraction. Some of these processes of groundwater salinization are discussed in more detail in the case studies below of (i) the management of salt-affected soils in the Indus Valley, Pakistan, and (ii) the monitoring and investigation of the causes of shallow aquifer salinity in the Namoi Catchment of NSW. 


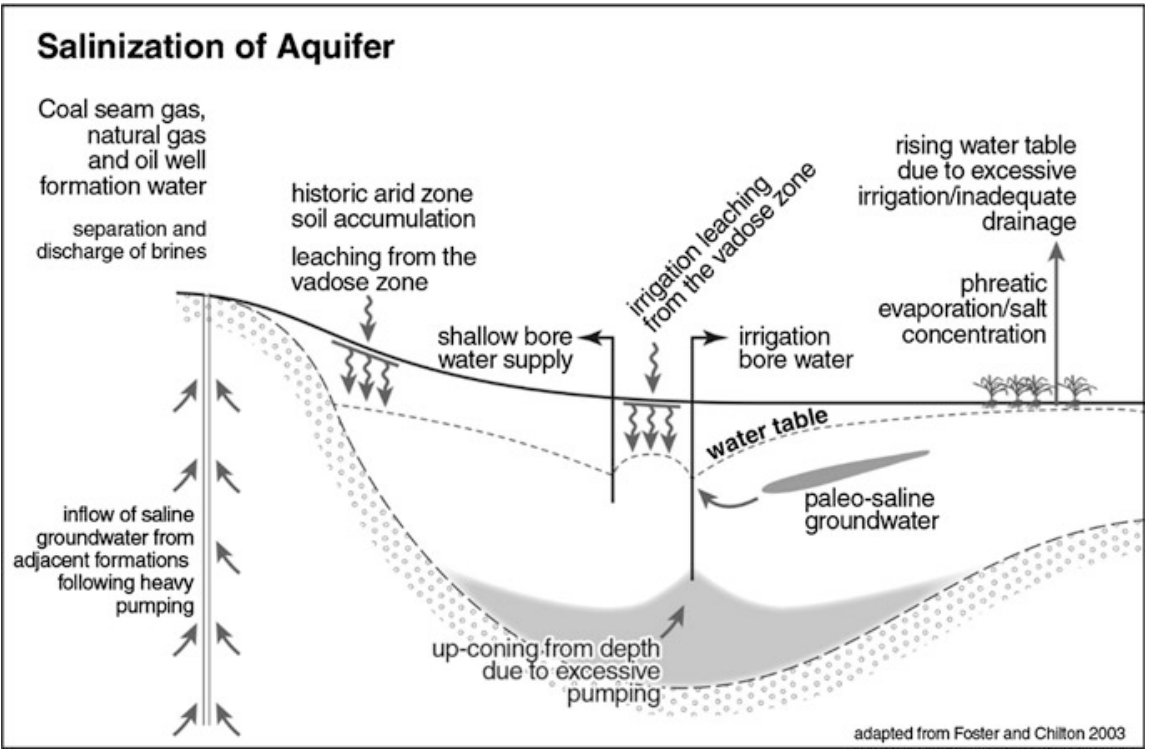

Fig. 15.4 Processes leading to salinization of aquifers in inland areas (After Foster and Chilton 2003)

\subsubsection{Aquifer Salinization in Coastal Areas Due to Intrusion of Salt Water}

Coastal floodplains around the globe constitute prime agricultural areas that generally rely on conjunctive use of surface water and groundwater, and this is largely controlled by the strong seasonality expressed in surface water supplies. As agricultural productivity has increased, traditional seasonal, opportunistic irrigation has been replaced by year-round development with seasonal surface waters augmented by groundwater during low-flow periods. Excessive pumping during groundwater extraction in coastal areas, however, can lead to salinization due to induced sea water intrusion. The hydraulic head of inland groundwaters is reduced by excessive pumping allowing seawater to encroach further inland, and thus salinizing the landscape (Fig. 15.5).

Once seawater intrudes and causes coastal salinization, it is almost impossible to remediate. Salinization of fresh groundwater in coastal aquifers is a global issue that is exacerbated by excessive groundwater extraction as well as by sea level rise (Werner et al. 2013). Under natural hydraulic equilibrium, a sloping interface between fresh and saline pore waters within an aquifer is located beneath the coastal plain (Fig. 15.5). Groundwater extraction at rates exceeding up-stream recharge by freshwater allows the interface to progress inland and locally may cause increased upwards and landward flow of saline seawater. The natural groundwater equilibrium is further susceptible to changes in recharge and discharge caused by climate change. Khan et al. (2006) have discussed how increasing rates 


\section{Seawater intrusion}

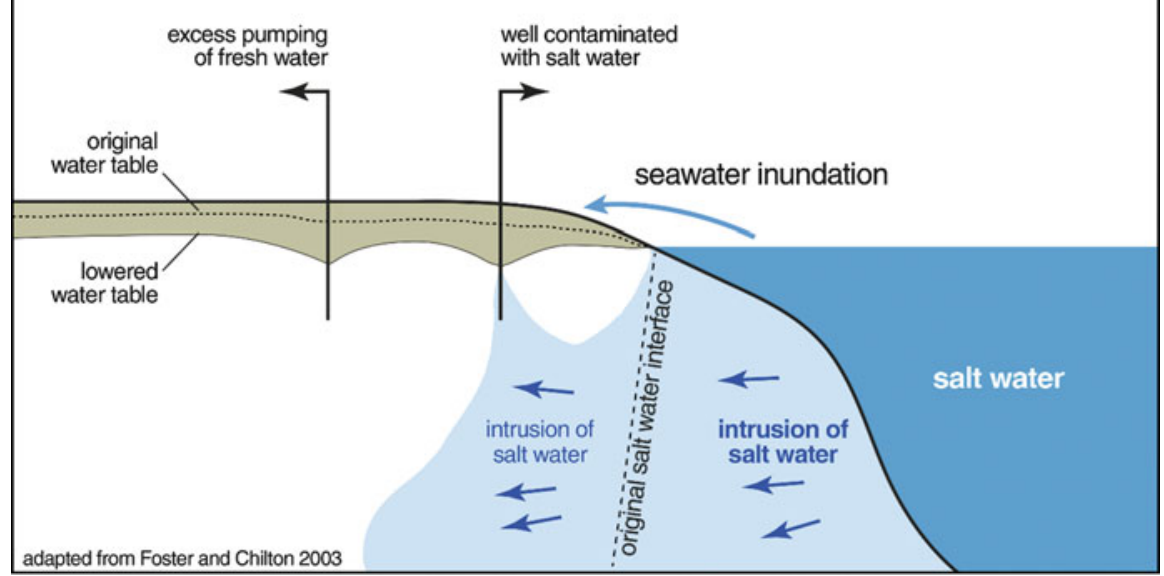

Fig. 15.5 Process leading to salinization of fresh groundwater in coastal aquifers due to the intrusion of salt water from the sea

of sea level rise due to global warming will increase the potential for intrusion of salt water in coastal areas of Bangladesh.

Critically, fresh water that is contaminated by only $5 \%$ of seawater renders it unsuitable for many beneficial uses without treatment. In low lying areas, salinization of fresh coastal aquifers commonly also occurs by inundation (Fig. 15.5), where seawater floods across the surface during storm surges or tsunami or as the land surface subsides. Seawater inundation infiltrates through soil to underlying aquifers as unstable lobes of saline water. Wong et al. (2015) also described how storm surges and sea-level rise resulted in the short-term inundation of low level coastal floodplain sediments. The inundation by either brackish water or seawater results in a decline in surface water quality due to increase liberation of acidity and trace metals.

\subsubsection{Aquifer Salinization Related to Extractive Resource Industries}

Resource extraction industries may also affect groundwater salinity as they physically interfere with existing aquifers and rock formations that are saturated with groundwater. Commonly, groundwaters associated with mineral resources (e.g. coal, oil and gas) exhibit high salinity and appropriate management is required to mitigate any contamination of fresher water supplies, soils and the environment.

Although the volume of water used by mining is typically small relative to other users, such as agriculture and the environment, cumulative volumes of groundwater that may require disposal can be large and, if challenges in managing salinity can be adequately addressed, this produced water presents significant opportunities as an 
alternative water supply for communities, industry, and the environment, albeit potentially short-lived (Timms and Bourke 2014).

As an example, management of salt at coal mining operations in the Hunter Valley involves multiple strategies to protect fresh surface waters. Farmers, concerned that increasing river salinity was impacting the irrigation of food and fodder crops, worked together with the mining and power generation industries to develop a world leading salt trading scheme. The Hunter River salt trading scheme (HRSTS) involves 13 mines and 3 power stations that trade salt credits permitting controlled release of saline water to the river during high flow events (Selman et al. 2009; Vink et al. 2013). Discharge volumes, salt concentrations and dilution factors are continuously monitored to achieve salinity targets at key points along the river. Allowable maximum salinity in the river during discharge events is set as $900 \mu \mathrm{S} / \mathrm{cm}$ at the most downstream monitoring point of the scheme. Thus, mine-site contribution to the salt load in the Hunter River, via controlled discharges, was contained to $3 \%$ of total river load under the HRSTS between 1995 and 2001 (David et al. 2003). Ultimately, however, if salt containment and dilution strategies are unable to achieve water quality objectives, active treatments such as desalination are required at some mine sites.

An additional salinity concern relates to final voids left following mine closure. These voids act as a point of groundwater recharge, or a hydraulic sink for local groundwater flow depending on local conditions. Evaporative concentration of saline groundwater in open voids often occurs, with the salinity of the void water increasing until salt solubilities are exceeded and precipitation occurs. This is a rare event however, as inputs of fresh runoff will delay the salinization. Geochemical modelling estimates of water quality in an open mine in the Hunter Valley, for example, indicates that it would take over 400 years for water salinity to exceed $4,000 \mathrm{mg} / \mathrm{L}$ (Hancock et al. 2005). A recent Environmental Impact assessment for a proposed open cut coal mine in the semi-arid Gunnedah Basin estimates $30,000 \mathrm{mg} / \mathrm{L}$ after $\sim 420$ years of evaporative concentration of inflowing groundwater at a salinity of $5,000 \mathrm{mg} / \mathrm{L}$ (Shenhua Watermark EIS 2013).

The recently developed water accounting framework for the minerals industry in Australia (MCA 2012), provides a common method to compare water balance and quality on a site-by-site basis and identifies three categories of water with respect to salinity to guide water use options, which may include dust suppression, industrial use or being suitable for potable supplies (Table 15.2).

Coal bed methane (CBM) operations, known as coal seam gas (CSG) in Australia, can generate large volumes of groundwater that may be quite saline and requires careful management to ensure that the risk of salinization to other groundwater and surface water supplies is negligible (Williams et al. 2012). Groundwater salinity could be impacted by CBM operations via a number of mechanisms including: mobilisation of saline groundwater through enhanced hydraulic gradients towards gas wells; leakage of saline groundwater through poorly sealed exploration bores and aging water supply bores; and surface spills from pipelines and storages for produced water and associated production fluids. Produced water volumes are typically highest during the early stages of CBM well 
Table 15.2 Water types and salinity classes

\begin{tabular}{l|l|l|l}
\hline Water type & EC $(\mathrm{dS} / \mathrm{m})$ & TDS $(\mathrm{mg} / \mathrm{L})$ & Mine Water ${ }^{\mathrm{a}}$ TDS $(\mathrm{mg} / \mathrm{L})$ \\
\hline Pure rainwater & $<0.015$ & $<10$ & \\
\hline Freshwater & $0.015-0.8$ & $100-1,000$ & $<1,000($ Category 1$)$ \\
\hline Slightly brackish water & $1.6-4.8$ & $1,000-3,000$ & $1,000-5,000($ Category 2$)$ \\
\hline Brackish water & $4.8-16$ & $3,000-10,000$ & $>5,000($ Category 3) \\
\hline Saline water & 16 & $>10,000$ & \\
\hline Seawater & 51.5 & 35,000 & \\
\hline Hyper saline & $>51.5$ & $>35,000$ & \\
\hline
\end{tabular}

${ }^{\mathrm{a}} \mathrm{MCA} 2012$

development as the system is depressurised to allow gas to desorb from the coal matrix. Risks to groundwater quality can typically be managed to reduce the risk of impacts to very low or negligible issues, although some concerns remain to be addressed. Disposal via evaporation and seepage ponds are no longer permitted in eastern Australian states and thus removes one of the highest risks to aquifer salinization. Temporary storage ponds, however, are still required and must be designed to minimise the risk of spills and seepage losses.

The salt content in produced CBM water varies widely, from nearly freshwater $(10-500 \mathrm{mg} / \mathrm{L})$ to salt levels up to ten times higher than seawater $(300,000 \mathrm{mg} / \mathrm{L})$. Lower concentrations tend to be associated with shallow coal seams exposed to recent fresh surface water recharge (Khan and Kordek 2014). In the Sydney Basin, existing CBM operations currently produce $<4.5 \mathrm{ML} /$ year of water with a salinity between 7 and $15 \mathrm{dS} / \mathrm{m}$ (i.e. TDS of 4,700-10,000 $\mathrm{mg} / \mathrm{L}$ ). The produced water is reused in drilling operations and the excess treated at a licensed water treatment facility. By contrast, CSG operations in the Surat Basin in South-east Queensland are projected to produce $20,000 \mathrm{ML} /$ year of water for 50 years with a TDS of 14,500-31,000 mg/L (OGIA 2012).

Produced water that is in excess of operational requirements will generally be treated by reverse osmosis desalination with discharge of suitably treated water for beneficial use. Beneficial use of mixed or treated water, for example to augment irrigation and environmental flows to rivers, is currently encouraged by regulatory agencies. Table 15.3 indicates water salinity limits for selected beneficial uses in Australia for irrigation of crops and for stock water. Water that is not suitable for drinking water $(>1.2 \mathrm{dS} / \mathrm{m})$ for example, is fit for the purpose of irrigating crops that are tolerant to brackish water.

Brine produced by desalination would be concentrated and recrystallized, typically for disposal to landfill. An alternative method of disposal of saline produced water by deep well injection could provide a local and permanent disposal solution for produced water or brine concentrates (National Research Council 2010). Commonly practiced in some parts of the US, deep well injection targets naturally saline formations that are hydraulically disconnected from fresh water aquifers (Yeboah and Burns 2011). 
Table 15.3 Salinity guidelines for key beneficial uses

\begin{tabular}{|c|c|c|c|}
\hline \multirow[t]{6}{*}{ Irrigation } & $\mathrm{EC}(\mu \mathrm{S} / \mathrm{cm})$ & Comments & Source \\
\hline & 8,000 & Unsuitable for barley irrigation & \multirow{10}{*}{$\begin{array}{l}\text { ANZEEC } \\
(2000)\end{array}$} \\
\hline & 7,700 & Unsuitable for cotton irrigation & \\
\hline & 5,500 & Unsuitable for sunflower irrigation & \\
\hline & 6,000 & Unsuitable for wheat irrigation & \\
\hline & 1,500 & $\begin{array}{l}\text { If used on early season cotton, the final yields could } \\
\text { be diminished }\end{array}$ & \\
\hline \multirow[t]{5}{*}{ Livestock } & $14,920^{\mathrm{a}}$ & $\begin{array}{l}\text { Loss of production and a decline in beef cattle } \\
\text { condition and health }\end{array}$ & \\
\hline & $10,450^{\mathrm{a}}$ & $\begin{array}{l}\text { Loss of production and a decline in dairy cattle and } \\
\text { horses condition and health }\end{array}$ & \\
\hline & $11,940^{\mathrm{a}}$ & $\begin{array}{l}\text { Loss of production and a decline in pigs condition } \\
\text { and health }\end{array}$ & \\
\hline & $5,970^{\mathrm{a}}$ & $\begin{array}{l}\text { Loss of production and a decline in poultry } \\
\text { condition and health }\end{array}$ & \\
\hline & $19,400^{\mathrm{a}}$ & $\begin{array}{l}\text { Loss of production and a decline in sheep condition } \\
\text { and health }\end{array}$ & \\
\hline \multirow{5}{*}{$\begin{array}{l}\text { Drinking } \\
\text { water }^{\mathrm{b}}\end{array}$} & $<120^{\mathrm{c}}$ & Excellent drinking water quality & \multirow{5}{*}{$\begin{array}{l}\text { ADWG } \\
(2008)\end{array}$} \\
\hline & $120-750^{\mathrm{c}}$ & Good drinking water quality & \\
\hline & $750-1,200^{\mathrm{c}}$ & Fair drinking water quality & \\
\hline & $1,200-1,490^{\mathrm{c}}$ & Poor drinking water quality & \\
\hline & $>1,490^{c}$ & Unacceptable drinking water & \\
\hline
\end{tabular}

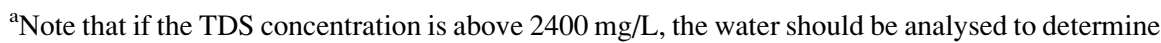
the concentrations of specific ions to avoid possible toxication (ANZEEC 2000)

${ }^{b}$ Bruvold and Daniels (1990) in Australian Drinking Water Guidelines (2008)

${ }^{\mathrm{c}} \mathrm{TDS}$ values converted to EC using equation: $\mathrm{EC}(\mu \mathrm{S} / \mathrm{cm}) \times 0.67=\mathrm{TDS}(\mathrm{mg} / \mathrm{L})($ ANZEEC 2000)

\subsubsection{Hydrogeochemical Changes During Salinization}

Examination of the changing proportions of dissolved ions in groundwater can reveal more information about the processes that lead to increased salinity or EC. Mixing and geochemical reactions that are common along a flow path change specific ion concentrations, or hydrochemical facies. Water recharged from meteoric sources is typically represented by fresh, bicarbonate-type water with mixed cation composition. Geochemical interactions between water and sediment, or rock, along a flow path typically results in evolution towards either a sodium bicarbonate water or sodium chloride water. Hypothetically, a series of hydrochemical facies occurs along a flow path, depending on the nature of sediment and rock encountered, that can indicate the maturity of a groundwater system.

A Piper diagram, as shown in Fig. 15.6, is a common method by which hydrochemical facies are represented. Relative concentrations of major cations are plotted in the lower left hand ternary plot, and relative concentrations of major anions are plotted in the lower right hand ternary plot. Both these sets of points are then projected to the central diamond, to intersect at a point that is indicative of hydrochemical facies. For example, Fig. 15.6 depicts facies change 


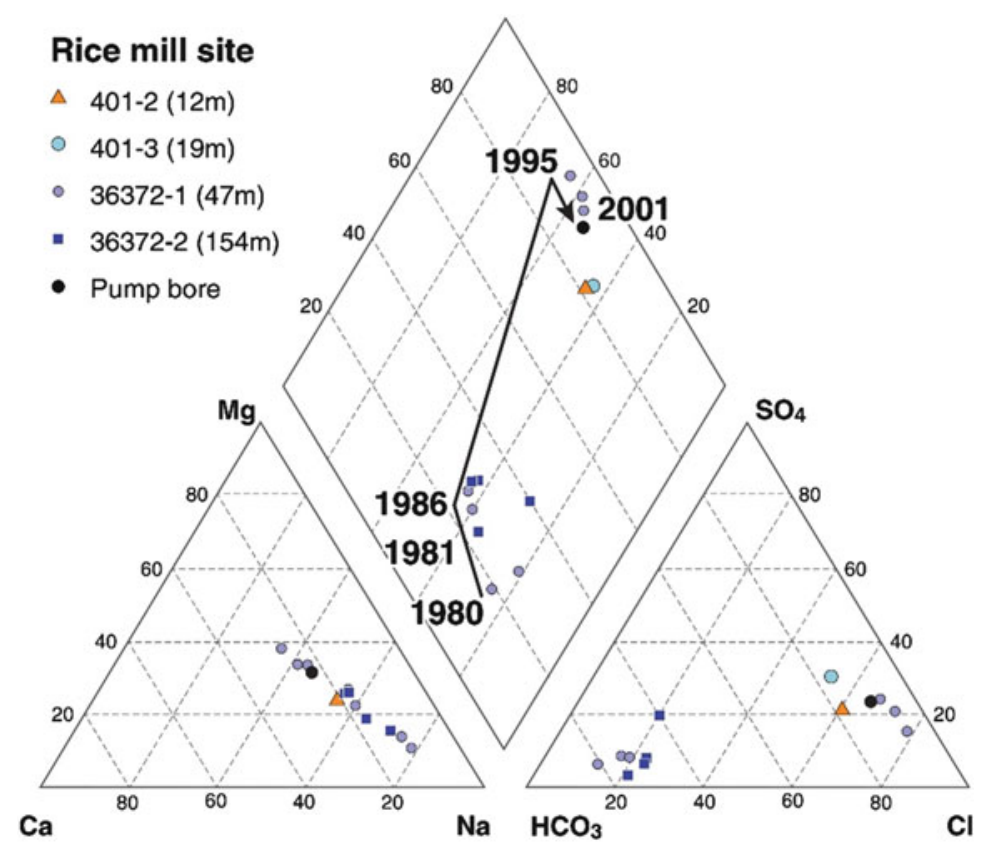

Fig. 15.6 Piper diagrams showing changes in major ion composition of groundwater at the Rice Mill site between 1980 and 2001 (After Timms 2001)

during salinization over two to three decades at a site (Rice Mill) in the Murrumbidgee Irrigation Area (MIA) of Australia's Murray-Darling Basin. At this site, groundwater in alluvial sediments at a depth of approximately $50 \mathrm{~m}$ increased in EC from $<0.5 \mathrm{dS} / \mathrm{m}$ to between 1.3 and $4.1 \mathrm{dS} / \mathrm{m}$. Concomitant with this change in EC, bicarbonate type water changed towards a chloride type water. The major ion composition of the deep groundwater also trended towards a similar composition, though less pronounced, and this was attributed to a downwards hydraulic gradient caused by groundwater extraction from the underlying aquifers, causing the leakage of groundwater from salt laden shallow sediments (Timms and Acworth 2002).

The primary geochemical reactions include dissolution of salts; ion exchange with clay minerals and surface sorption and desorption reactions. These geochemical reactions proceed towards chemical equilibrium and can therefore be assessed using models based on thermodynamic chemical databases. A simple approach utilises a water mixing diagram that can be developed prior to geochemical modelling based on conservative ion (e.g. chloride) concentrations of end members such as saline and fresh groundwater. Figure 15.7, for example, illustrates that at high mixing ratios, based on conservative ion mixing, $\mathrm{HCO}_{3}$ and $\mathrm{SO}_{4}$ concentrations are non-linear indicating processes other than mixing controlling concentration. A relative increase of $\mathrm{Na}$ in fresh water samples is evident, 


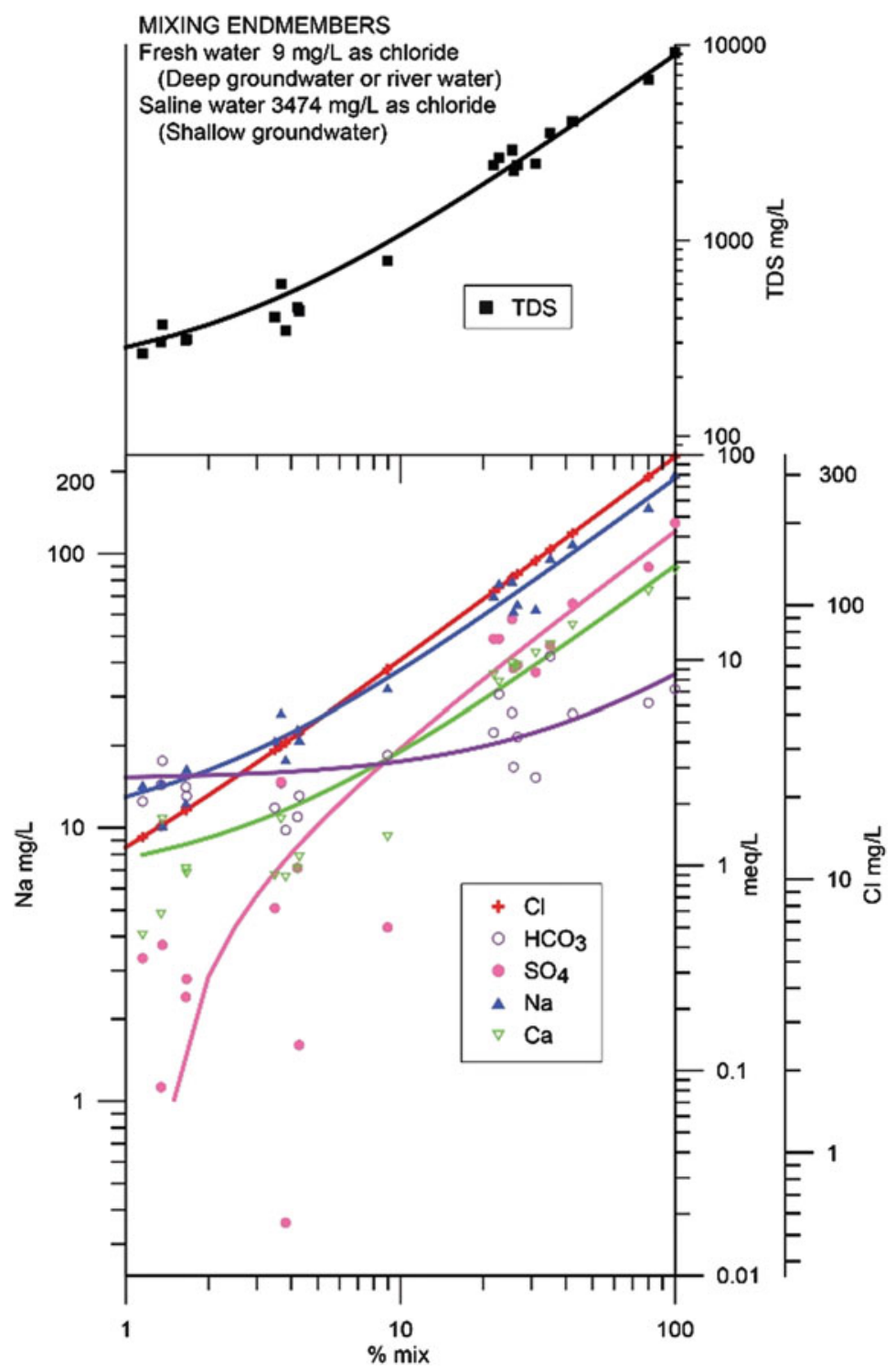

Fig. 15.7 Mixing diagram for groundwaters $(N=44)$ arranged along the $X$ axis in terms of $\%$ mix of saline groundwater of $3,474 \mathrm{mg} / \mathrm{L}$ chloride in fresh water of $9 \mathrm{mg} / \mathrm{L}$ chloride (After Timms 2001)

indicating ion-exchange is an important geochemical process that occurs during mixing. Incorporation of geochemical mixing models to help understand salinization processes can aid in determination of appropriate mitigation strategies and management controls. 


\subsection{Salinization Case Studies}

This section illustrates the scale of the problem of groundwater salinization as influenced by management and policy through two case studies in a developing and a developed country, i.e. Pakistan and Australia, respectively. The case study from Pakistan focuses mainly on soil salinization, whilst the case study from the Namoi catchment particularly assesses aquifer salinization.

\subsubsection{Case Study 1: Rehabilitation of Salt Affected Lands in the Wheat-Cotton Zone of Pakistan; a Physical and Economic Approach to Water Logging and Irrigation Salinity}

\subsubsection{Overview}

In Pakistan approximately $80 \%$ of the agricultural production comes from irrigated agriculture. However, waterlogging and irrigation salinity are major land degradation problems that result in severe economic and social consequences. Out of the total 16.3 million ha of irrigated land in Pakistan about 6.2 million ha (38\%) are waterlogged, and 2.3 million ha $(14 \%)$ are saline. The irrigation salinity results from the intensive use of surface irrigation, where the salt accumulates in the soil surface layers due to a major imbalance in the amount of salt entering and leaving the soils. As a consequence yields and production of crops are adversely affected, resulting in severe economic losses. In 2001 these losses were estimated to be 350 million US\$ annually. Thus salinity management can offer opportunities to alleviate poverty and improve rural livelihoods. Economically, a viable choice of the salinity management is needed to guide decisions for future salinity investments.

Eastern Sadiqia South region in the wheat-cotton zone of Punjab province has been used as a case study. The aim of this study was to (i) conduct a cost benefit analysis of implementing three management strategies, i.e. no intervention, an engineering approach, and an agronomic approach, on four land types, and (ii) compare the Net Present Values (NPV) of the three strategies on the four land types over a period of 25 years, using a discount rate of $6 \%$. The results of the study will enable us to define criteria and set out rules for investment in the rehabilitation of salt-affected lands.

\subsubsection{Background}

The Fordwah canal command area of Eastern Sadiqia South (FESS) region is located in the wheat-cotton zone of Punjab province, and forms part of the Indus Basin irrigation system. The area is situated on the left bank of the River Sutlej (Fig. 15.8).

The climate of the regions is arid (PARC 2002), with annual evaporation of $2,000 \mathrm{~mm}$, far in excess of the annual rainfall of $240 \mathrm{~mm}$ (Sarwari et al. 2000). The soils of the area are comprised mainly of a wide range of coarse to fine textured 


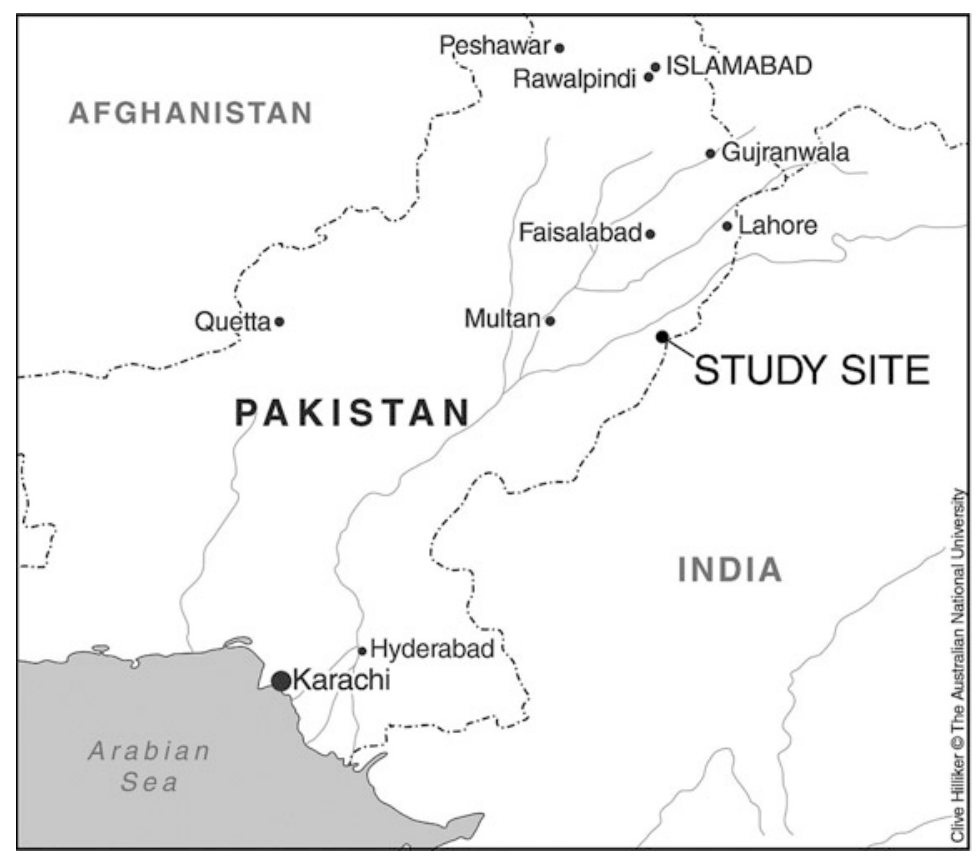

Fig. 15.8 Location of Eastern Sadiqia region, the study area (Source: Pakistan Agriculture Research Council 2002)

alluvial deposits, dominated by medium textured silty loams, with a low to medium water holding capacity (Sarwari et al. 2000). In the majority of cases, farmers use flood irrigation (Kijne 1996), sourced from canal water with an average EC value of $0.3 \mathrm{dS} / \mathrm{m}$ (IWMI 2007). Groundwater in most of the region, however, is saline with EC $>4 \mathrm{dS} / \mathrm{m}$ (Aslam and Prathapar 2006), making groundwater mostly unsuitable for irrigation purposes. Deep percolation from the irrigation system of canals, combined with general lack of good drainage, has resulted in water logging and a major imbalance in the amount of salt entering and leaving the soils. The water logging and salt accumulation have caused various degrees of degradation (Fig. 15.9) (Kahlown and Azam 2002).

Four different land categories were identified (Fig. 15.9) based on the severity of water logging (depth of water table) and soil salinity (ECe) (Table 15.4). They ranged from Land Class D1 which was extremely degraded land through to Land Class 4 which was normal land. Three different salinity management strategies were investigated, i.e. 1. no intervention and use of existing land-use cropping activities, 2. an engineering approach where excessive water is drained from the irrigated land, and 3. an agronomic approach whereby crop diversification, e.g. kallar grass and sesbania, and planting of deep rooted vegetation, e.g. River Red Gum, were used. 


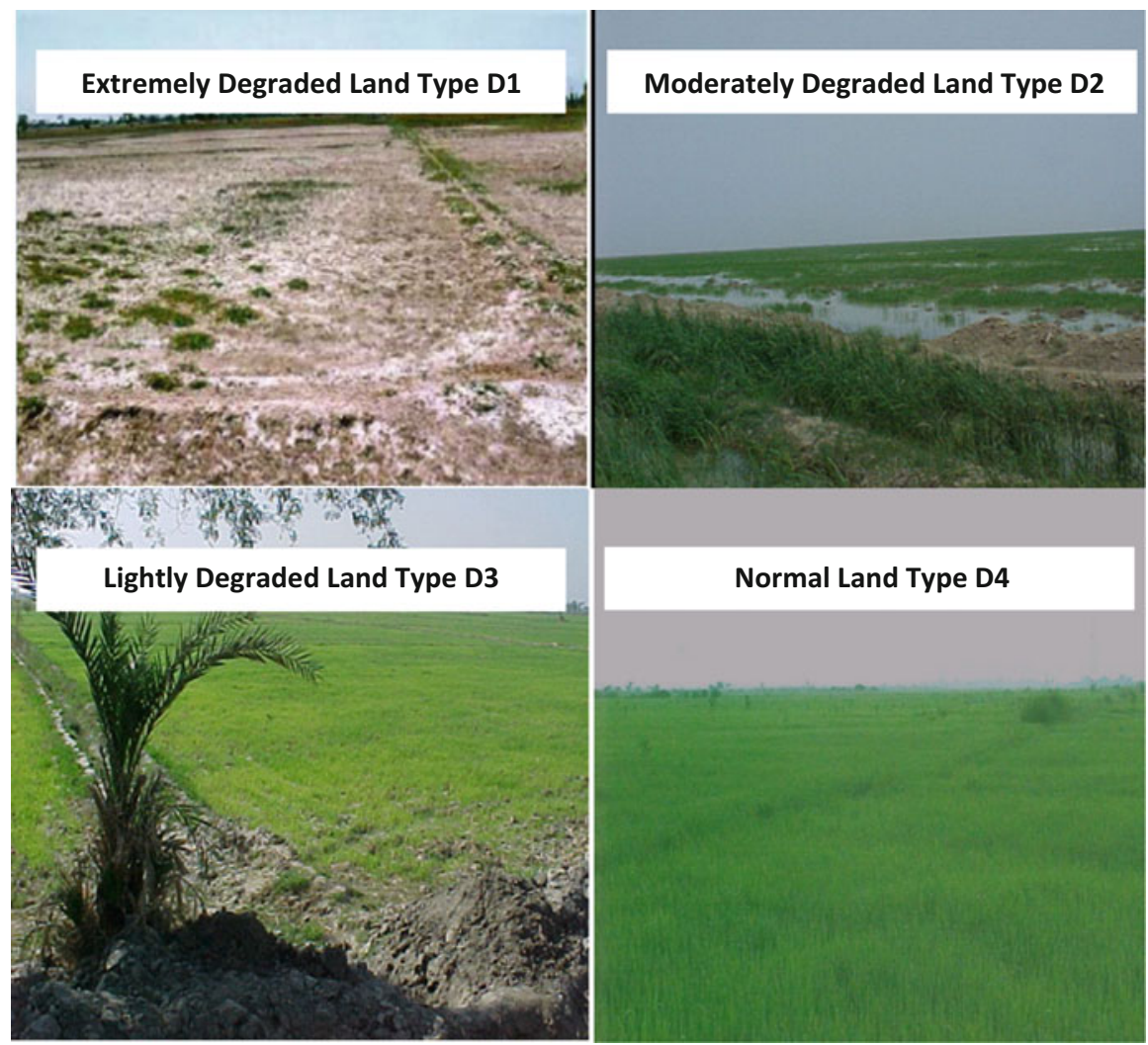

Fig. 15.9 Land types of the Eastern Sadiqia region (Compiled from IWMI 2007)

Table 15.4 Criteria for land categories in the Eastern Sadiqia (FESS) region (Adapted from PARC 2002)

\begin{tabular}{l|l}
\hline Land category & Description \\
\hline D1 Extremely degraded land & Watertable $<1 \mathrm{~m}$ and ECe $>12 \mathrm{dS} / \mathrm{m}$ \\
\hline D2 Moderately degraded land & Watertable $1-2 \mathrm{~m}$ and ECe between 8 and $12 \mathrm{dS} / \mathrm{m}$ \\
\hline D3 Lightly degraded land & Watertable $2-3 \mathrm{~m}$ and ECe between 4 and $8 \mathrm{dS} / \mathrm{m}$ \\
\hline D4 Normal land & Watertable $>3 \mathrm{~m}$ and ECe between 0 and $4 \mathrm{dS} / \mathrm{m}$ \\
\hline
\end{tabular}

\subsubsection{Physical Analysis of Effects of Salinity on Soils and Crops}

A salt balance model proposed by Hillel (2000) (Fig. 15.10) was used to calculate the rate of salt accumulation under the four land categories. The model identifies five sources of salt inputs: the salt already present in the mineral soils; the salt entering the root zone from irrigation water; salt addition through land management practices such as fertilizers; salt addition through rainwater; and the salt entering 


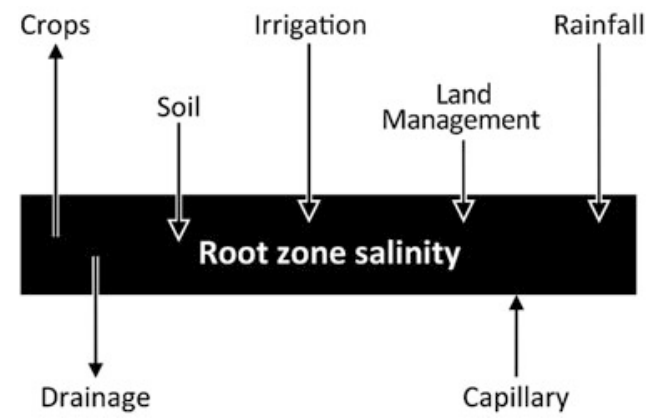

Fig. 15.10 Salt balance calculation model proposed by Hillel (2000)

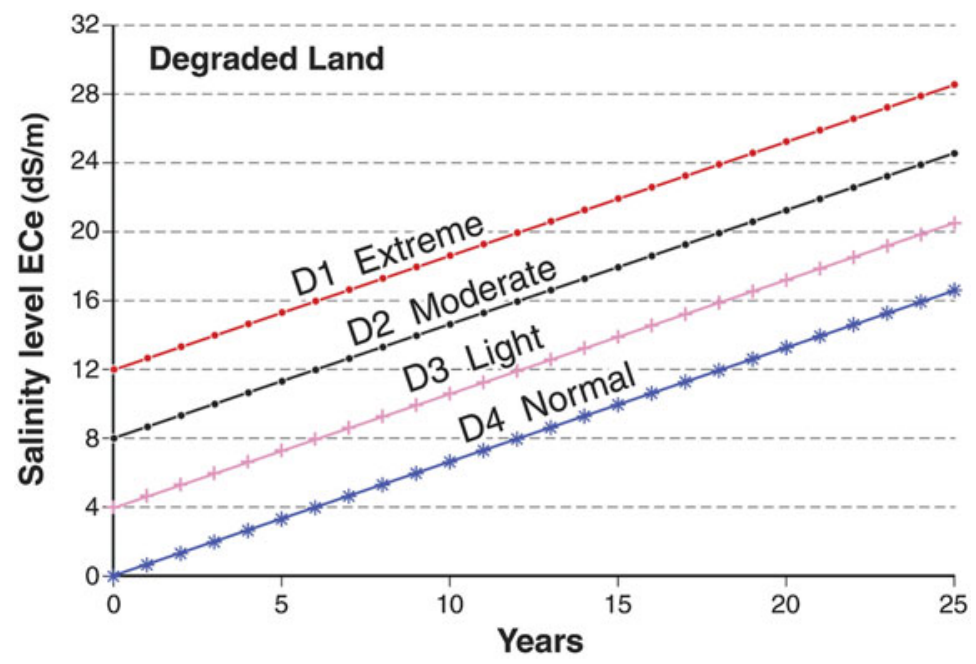

Fig. 15.11 Salinity projections for the next 25 years in the study area

the root zone from groundwater through capillary rise (Fig. 15.10). The factors of salt removal include removal by the crops and by natural drainage.

Figure 15.11 indicates the increasing trend of land salinity for the next 25 years in the four major categories of land (D1, D2, D3, and D4) present in the study area under irrigated agriculture and with no management strategy in place. The annual rate of salt accumulation was calculated to be $0.420 \mathrm{~kg} / \mathrm{m}^{2}$ or $0.66 \mathrm{dS} / \mathrm{m}$ (Arshad 2007). Wheat and cotton crop yields start to decrease with the increase in the salinity levels for each year. Figure 15.12 shows the trend of wheat and cotton crop yields under the influence of salinity. There is no effect of salinity on both crops up to an ECe of $4 \mathrm{dS} / \mathrm{m}$; however, after an ECe of $4 \mathrm{dS} / \mathrm{m}$, yield of both crops show a rapid decrease with increase in ECe, with wheat being the most affected. 


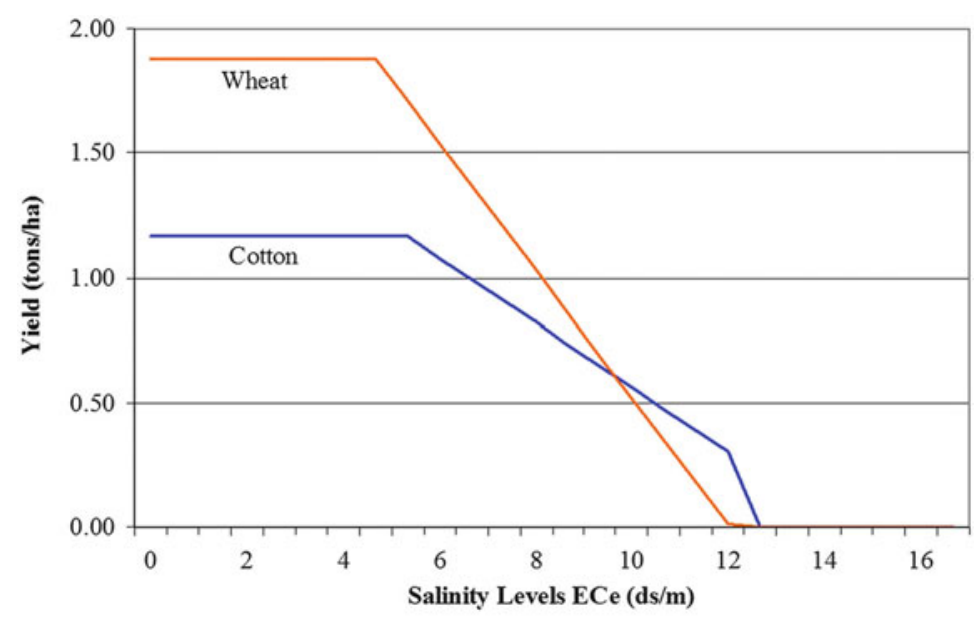

Fig. 15.12 The effect of increasing salinity levels on wheat and cotton yields in the study area

Table 15.5 Net present values (NPV) for three salinity management strategies (US \$/ha)

\begin{tabular}{l|l|l|l}
\hline Land type & $\begin{array}{l}\text { No management } \\
\text { strategy }\end{array}$ & $\begin{array}{l}\text { Engineering } \\
\text { strategy }\end{array}$ & $\begin{array}{l}\text { Agronomic } \\
\text { strategy }\end{array}$ \\
\hline $\begin{array}{l}\text { D1 Extremely degraded } \\
\text { land }\end{array}$ & -408 & 673 & 1,078 \\
\hline $\begin{array}{l}\text { D2 Moderately degraded } \\
\text { land }\end{array}$ & 57 & 1,042 & 477 \\
\hline D3 Lightly degraded land & 1,544 & 1,074 & 477 \\
\hline D4 Normal land & 3,500 & 49 & 95 \\
\hline
\end{tabular}

\subsubsection{Results of the Cost Benefit Analysis}

By considering the four land types (D1, D2, D3, and D4) this desktop study compares the Net Present Values (NPV) of the two diverse management strategies, of engineering and agronomic options, with the no intervention strategy. Table 15.5 highlights the rehabilitation strategies that maximise Net Present Values for the four land types over a period of 25 years. A discount rate of $6 \%$ was applied to all three strategies analysed.

The results of the cost benefit analyses in the study area indicate several important outcomes:

Firstly, for the extremely degraded land type D1, the agronomic strategy will result in the highest farm benefits in the next 25 years. Managing extremely degraded land type D1 with the engineering strategy ranked 2nd, and with the no management strategy ranked 3rd. Secondly, for the moderately degraded land type D2, the engineering strategy provides the best economic solution, when compared with the agronomic strategy which ranked 2nd, and the no management strategy which ranked 3rd. Thirdly, for the lightly degraded land type D3, no management is the best economic strategy. After the no management strategy, the engineering 
strategy ranked 2nd and the agronomic strategy ranked 3rd. Fourthly, for the normal land type D4, the no management strategy provided the highest benefits followed by the agronomic strategy which ranked 2 nd and the engineering strategy which ranked 3rd.

One limitation of the previous analysis, where the criteria for the rehabilitation of salt affected lands are purely economic, is that it will encourage farmers to maximise profits at the cost of soil and land degradation. For example results in Table 15.2 suggest that the No Management Strategy for Land types D3 (NPV, 1,544 \$/ha) and D4 (NPV 3,500 \$/ha) is the best economic option. This implies that both the productive Normal and Lightly Degraded Lands under irrigation should be managed according to normal practice without any additional salinity management. However, following only this economic criteria, the two land types D3 and D4 will become extremely salinized by the end of years 12 and 18 respectively, with salinity levels $\mathrm{EC}_{\mathrm{e}}$ exceeding $12 \mathrm{dS} / \mathrm{m}$ (Table 15.4 and Fig. 15.11). Thus a long term farm plan considering $\mathrm{a} \geq 50$ year scenario may encourage farmers to initially degrade the productive lands (D3 and D4) in the first 25 years and concurrently restore the degraded lands (D2 and D1) via an engineering and agronomic strategy respectively. However, in the second 25 year period, theoretically the initially productive lands (D3 and D4) which have now become degraded due to salinization, should undergo active rehabilitation via an engineering or agronomic strategy. Similarly land types D1 and D2 which were initially extremely and moderately degraded respectively and became productive after 25 years, should in the next 25 years be managed without any additional inputs.

In summary, this study serves as a decision support tool for funding agencies to undertake future investments in salinity management. The study informs two guiding principles for the salinity management policy in Pakistan: first, highly degraded lands such as D1 and D2 should be given priority for salinity rehabilitation (via an engineering and agronomic strategy respectively) over the relatively productive lands such as D3 and D4; and second a longer period of analysis of at least 50 years should be adopted for determining economic viability of salinity investment strategies. However even though a $\geq 50$ year scenario may be adopted such an approach is still limited because it only considers economic criteria and doesn't take into account broader environmental factors such as (i) climate change, and (ii) the problem of how to dispose of the salt in the long term and how to prevent this salt contaminating other areas. Such factors may adversely impact on the long-term sustainability of irrigated agriculture in the region.

\subsubsection{Case Study 2: Groundwater Salinity Changes in the Namoi Catchment}

\subsubsection{Overview}

The salinity of alluvial aquifers in the Namoi catchment, located in the north-west of Australia's Murray-Darling Basin, has changed over the last several decades. Since the mid-1980s, groundwater from some bores has become more saline, while 
in others groundwater has become fresher (Badenhop and Timms 2012). Aquifer salinization processes in the Namoi catchment area could be attributed to several processes that mobilize salt from shallow soils and aquifers. These are investigated below.

\subsubsection{Background}

The Namoi catchment covers an area of approximately $42,000 \mathrm{~km}^{2}$ and is located in northeast New South Wales in a semi-arid to arid setting with summer-dominant rainfall. In the Namoi catchment, 112,000 ha of land is irrigated to grow cotton, wheat and other crops, using a combination of surface-water and groundwater supplies depending on water availability (CSIRO 2007). Groundwater resources occur primarily in semi-confined, alluvial aquifers up to $100 \mathrm{~m}$ depth and exhibit complex hydraulic connectivity pathways (Kelly et al. 2014). Relatively low, fresh to saline, groundwater yields are achieved from multiple watertable alluvial aquifers with additional supplies from porous and fractured rock aquifers accessed on ridges above the black soil plains, and from beneath the alluvial aquifer system.

Low salinity groundwater is required for the environment, stock water and for irrigation in the Namoi Catchment, to support an industry worth at least $\$ 380$ million each year. In addition, potable drinking water supplies are sourced almost exclusively from groundwater in this semi-arid region. Continued extraction has resulted in a clear trend of falling groundwater levels, with up to $14 \mathrm{~m}$ drawdown in some areas since the beginning of the groundwater withdrawals in the 1960s, with the growth of the irrigation industry and development of groundwater management approaches in the area and response to historic and recent flooding (Kelly et al. 2013).

\subsubsection{Groundwater Salinity Changes over Time}

In the late 2000s, the Namoi Catchment Management Authority (CMA) commissioned a study to evaluate groundwater salinity changes across both the Lower and Upper Namoi catchments (Timms et al. 2009). Historic data was compiled and at-risk and representative bores across the region were re-sampled (Timms et al. 2009; Badenhop and Timms 2012). In that study, the variability of groundwater quality across the catchment and over time was augmented with new data. Standard protocols were used to test $\sim 60$ samples at 45 bores on three occasions during 2009 with a total of 189 field parameter records and 121 major ion analyses. Groundwater salinity was found to be relatively stable at most sites where sufficient historic data was available (105 monitoring pipes), although significant groundwater salinity increases occurred over the past two decades at about $20 \%$ of sites. Salinity increases were most concentrated to the east and southeast of Gunnedah (Fig. 15.13). This is an area with intensive groundwater extraction and where naturally high salt stores within three metres of the surface occur (Fig. 15.13). One of the worst cases was a bore screened at $80 \mathrm{~m}$ depth where the average EC from monitoring in 2000-2009 (8.8 dS/m) was $156 \%$ higher than the average from 1980 to 1999 (3.5 dS/m). In contrast, groundwater in other bores in the area was found to be fresh. An update to the original analysis (Badenhop and 


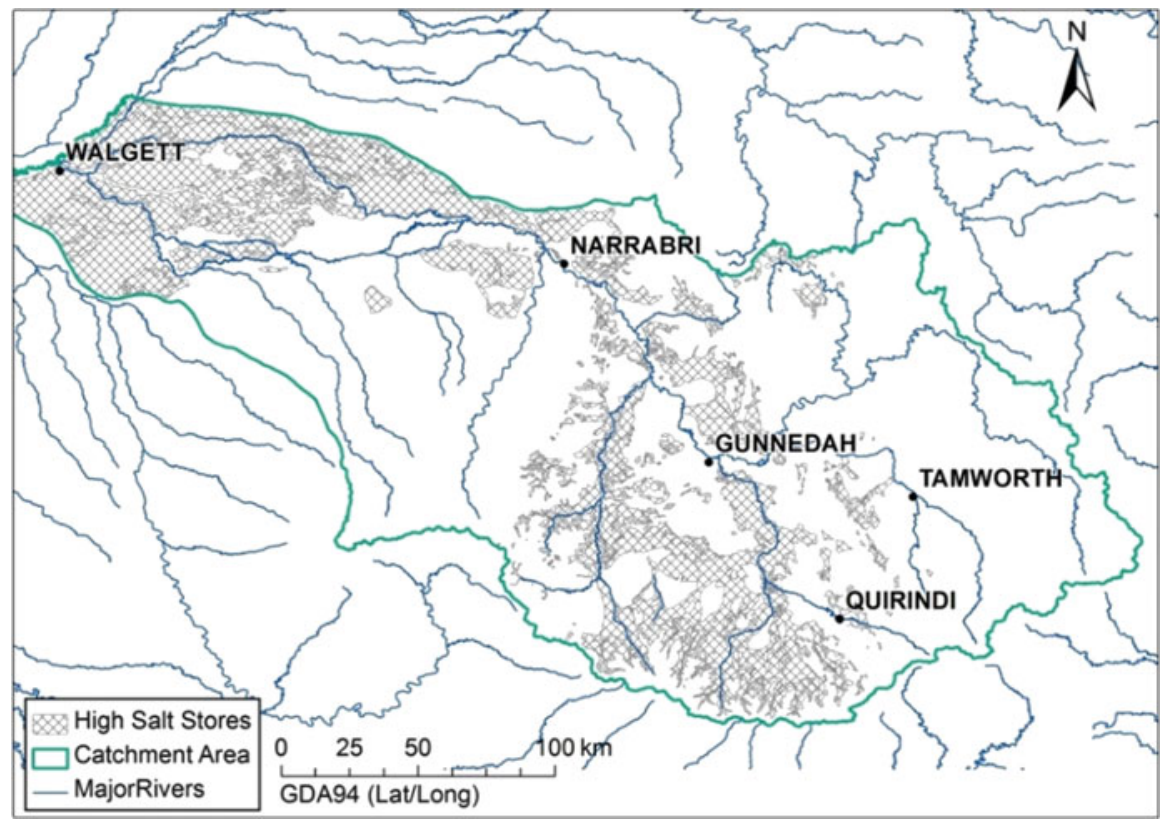

Fig. 15.13 Salt store in upper $3 \mathrm{~m}$ of soil in Namoi catchment (Namoi CMA)

Timms 2012) found that freshening had occurred at about $25 \%$ of sites that had sufficient data over the same period (Fig. 15.14). This figure shows the lack of comparative EC data in many areas, and the spatial non-uniformity in salinization and freshening.

Earlier studies of groundwater salinity changes focused on processes at research sites or were limited in scope to restricted parts of the Namoi catchment. Agriculture-induced salinity is a well-documented soil and land management issue on the adjacent Liverpool Plains, a part of the Upper Namoi catchment (e.g. RingroseVoase et al. 2003) and broad trends of aquifer salinization since the 1980s have been identified by Lavitt (1999) in the Mooki River area, to the east of Gunnedah. These are attributed to extraction of groundwater and increased downwards flux of saline water from clayey silt deposits. In areas dominated by groundwater fed irrigation, complex hydrochemical variations occur to a significant depth in the system during and after significant periods of groundwater extraction (Timms and Acworth 2002; Timms and Ackworth 2009).

The potential for mixing of fresh and saline groundwaters induced by groundwater pumping is a major concern for both the Lower and Upper Namoi catchments. Studies by McLean et al. (2011) indicate that salinity is increasing at several hotspots, due to several factors including changing hydraulic gradients, and leaching of salt-laden sediments. The beneficial use of groundwater was found to have deteriorated since monitoring began, with some bores no longer suitable for 


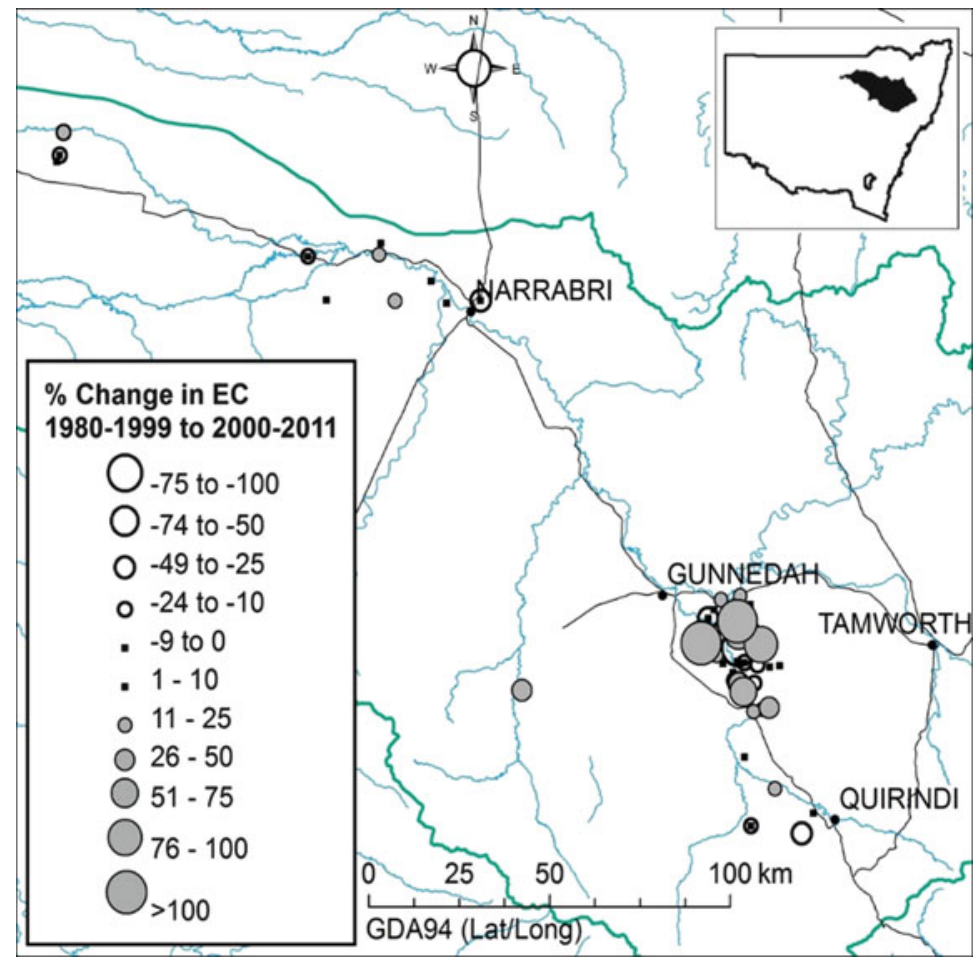

Fig. 15.14 Hot spot of groundwater salinity changes near Gunnedah showing a non-uniformity in salinization and freshening (After Badenhop and Timms 2012)

stock (generally noted in shallow bores), or no longer suitable for irrigation of some crops, including cotton (notably in the deeper bores).

Groundwater chemistry changes due to mixing induced by irrigation pumping were also observed in the Lower Namoi irrigation area by Barrett et al. (2006). The increase in salinity in this area, however, remained within the beneficial use limits for irrigation. In the western, arid parts of the Namoi, there is no irrigation to mobilize salts, but there is evidence (Timms et al. 2012) that clearing of native vegetation has caused a salt bulge in the soil to leach downwards. Total salt loads of 91-229 t/ha $\mathrm{NaCl}$ equivalent were measured for deep salt stores (from the ground surface to $10 \mathrm{~m}$ depth) for both perennial vegetation and cropping sites, despite salinity not being detected by shallow soil surveys, that are typically limited to $2-3 \mathrm{~m}$ depth. Groundwater salinity varied spatially from $0.9 \mathrm{dS} / \mathrm{m}$ to $2.4 \mathrm{dS} / \mathrm{m}$ at $21-37 \mathrm{~m}$ depth $(\mathrm{N}=5)$, whereas deeper groundwater remained less saline $(0.3 \mathrm{dS} / \mathrm{m})$.

\subsubsection{Salinization and Freshening Processes in Aquifers}

Aquifer salinization in this inland groundwater system has been attributed to several processes. Multiple processes are required to explain the isolated and patchy nature of the temporal trends across the catchment. The most significant aquifer 
salinization processes in this area thus include: (i) leaching of saline soils with increased recharge; (ii) downward and lateral flow of shallow saline groundwater into deeper fresh aquifers as hydraulic gradients are enhanced by extraction of deep fresh alluvial aquifers for irrigation, and (iii) possible leakage that occurs at some locations via aging and poorly constructed bores whereby water from shallow saline aquifers leaks into deeper fresh aquifers.

All processes suggested by Foster and Chilton (2003) (Fig. 15.4) may have affected salinization of shallow groundwater in localised areas of the Namoi catchment. However, the processes that have led to salinization of deeper alluvial aquifers used for irrigation still require further investigation. Leaching of saline soils is likely to be more significant in areas with relatively high permeability soils and where ponding occurs in areas of relatively low surface elevation (Timms et al. 2012).

Shallow, saline groundwater has long been an issue for land management in the Namoi (Abbs and Littleboy 1998; Ringrose-Voase et al. 2003) and is also a threat to salinization of deeper fresh aquifers (Badenhop and Timms 2012). Mobilization of saline groundwater that occurs in stratified sediments, either via lateral flow, or from leakage from overlying sediments with variable salt content, could account for the patchy and localised nature of the groundwater salinity trends observed (Badenhop and Timms 2012). The degree of dilution of saline groundwater by fresh groundwater within aquifers is unknown, though mixing within pore waters of the layered sedimentary alluvium may be limited. Enhanced hydraulic gradients due to groundwater pumping for irrigation influence aquifers with good hydraulic connectivity, although there can be significant time delays for changes to occur is less hydraulically connected aquifers (Kelly et al. 2013).

Due to the possible leakage from aging, or poorly constructed, bores (Fig. 15.15) causing salinization of groundwater (Santi et al. 2006), newly revised construction guidelines (NUDLC 2012) for water bores in Australia emphasise the need for appropriate annulus seals, rehabilitation and decommissioning procedures (Timms and Acworth 2009). However, there is anecdotal evidence of irrigation bores having been recently constructed in the Namoi area with gravel pack filling the annulus between the deep alluvial aquifer to the surface, potentially allowing shallow saline groundwater a conduit for leakage into deeper fresh aquifers. For example, the salinity of fresh groundwater could double from 0.2 to $0.4 \mathrm{dS} / \mathrm{m}$ by mixing with just $1.7 \%$ of saline groundwater at $12 \mathrm{dS} / \mathrm{m}$. The National Water Commission estimated that NSW has a liability to replace at risk monitoring bores at a cost in the order of $\$ 35.6$ million, mainly for $\sim 800$ monitoring bores constructed of steel casing or screen that are aging (NWC 2012). Although many of the monitoring bore casings in the Namoi are PVC rather than steel that is susceptible to failure, no account has been taken of the failure of bentonite seals in the NWC (2012) review of groundwater monitoring infrastructure.

\subsubsection{Freshening processes}

Freshening of groundwater observed by Timms et al. (2009) at some bores near the river was attributed to changes in gaining and losing stream patterns. Many 


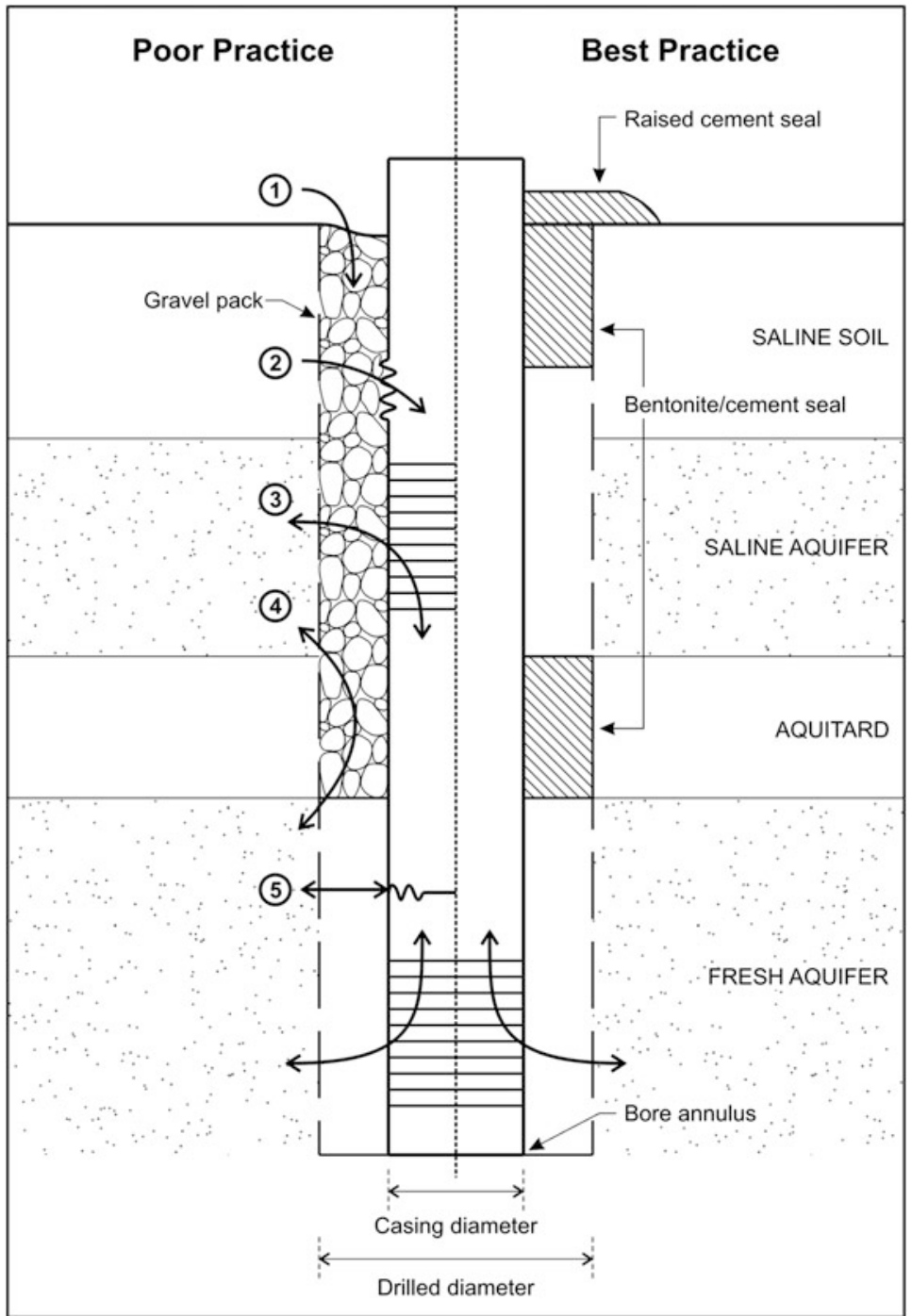

(1) Leakage from ground surface/storm runoff

(2) Leakage through corroded casing

(3) Leakage within bore with multiple or long intake screens

(4) Leakage through non-sealed annulus (eg. gravel pack)

(5) Leakage via leaky casing join

Fig. 15.15 Leakage pathways for groundwater in poorly constructed, or failed, groundwater bores (After Timms and Acworth 2009) 
locations that were once gaining streams are now losing streams due to development of the groundwater resources (CSIRO 2007; Andersen and Acworth 2009; McCallum et al. 2014). Prior to extensive development of the Lower Namoi alluvium, recharge from stream losses would have been about 9 GL/yr., whilst from 1980 to 1998 stream loss accounted for an average of $41 \mathrm{GL} / \mathrm{yr}$. This enhanced stream loss could lead to freshening of groundwater as river water is typically of lower salinity. The impacts of current levels of extraction on stream loss are yet to be fully realised (Kelly et al. 2013), and further changes in flow rates and salt fluxes will occur in the future.

\subsubsection{Beneficial Use Impact}

The NSW Groundwater Protection Policy contains the management principle that "All groundwater systems should be managed such that their most sensitive identified beneficial use (or environmental value) is maintained" (NSW DLWC 1998). Average EC for the period 2000-2005 was used by Timms et al. (2009) to assess the beneficial use across the catchment as a reference to determine if changes had occurred. The majority of waters across the Namoi Catchment were found to be suitable for drinking water, with waters only suitable for irrigation and livestock in selected areas of the Upper Namoi, and in the north-west as well as those areas furthest from the Namoi River in the Lower Namoi alluvium.

An analysis was completed by Timms et al. (2009) to determine if there had been any recent changes in beneficial use, comparing data from 2000 to 2005 to data from 2006 to 2009. Unfortunately, only 27 of 1,268 monitoring bores had sufficient data for both time periods. Of these bores, only one showed a degraded beneficial use category within the broad definitions of drinking, irrigation and poultry, and livestock (Table 15.2). However, if the resolution of beneficial use category is increased to define changes that inhibit the growth of specific crops, the findings change. While mature cotton can be irrigated with water EC up to $7.7 \mathrm{dS} / \mathrm{m}$, early season cotton tolerates only water with $\mathrm{EC}<1.5 \mathrm{dS} / \mathrm{m}$ (Fig. 15.16). A risk assessment of groundwater resources in the Namoi identified four areas where changes in salinity might occur in the future that require strategic monitoring and management strategies.

\subsubsection{Integrated Management Responses}

Management responses to groundwater quality issues include: local initiatives; regional efforts to understand and raise awareness, and state-based regulatory approaches. These approaches include policy and compliance functions consistent with Murray-Darling Basin Authority and National water reforms (Holley and Sinclair 2012 and Chap. 9).

\section{Local Level}

At a local level, the keys to efficient on-farm irrigation water management are knowing how much water in the soil profile is available to the crop and how much water the crop needs (Charlesworth 2005). This will minimise accessions of surface water and potential salt leaching into lower fresh aquifers. 


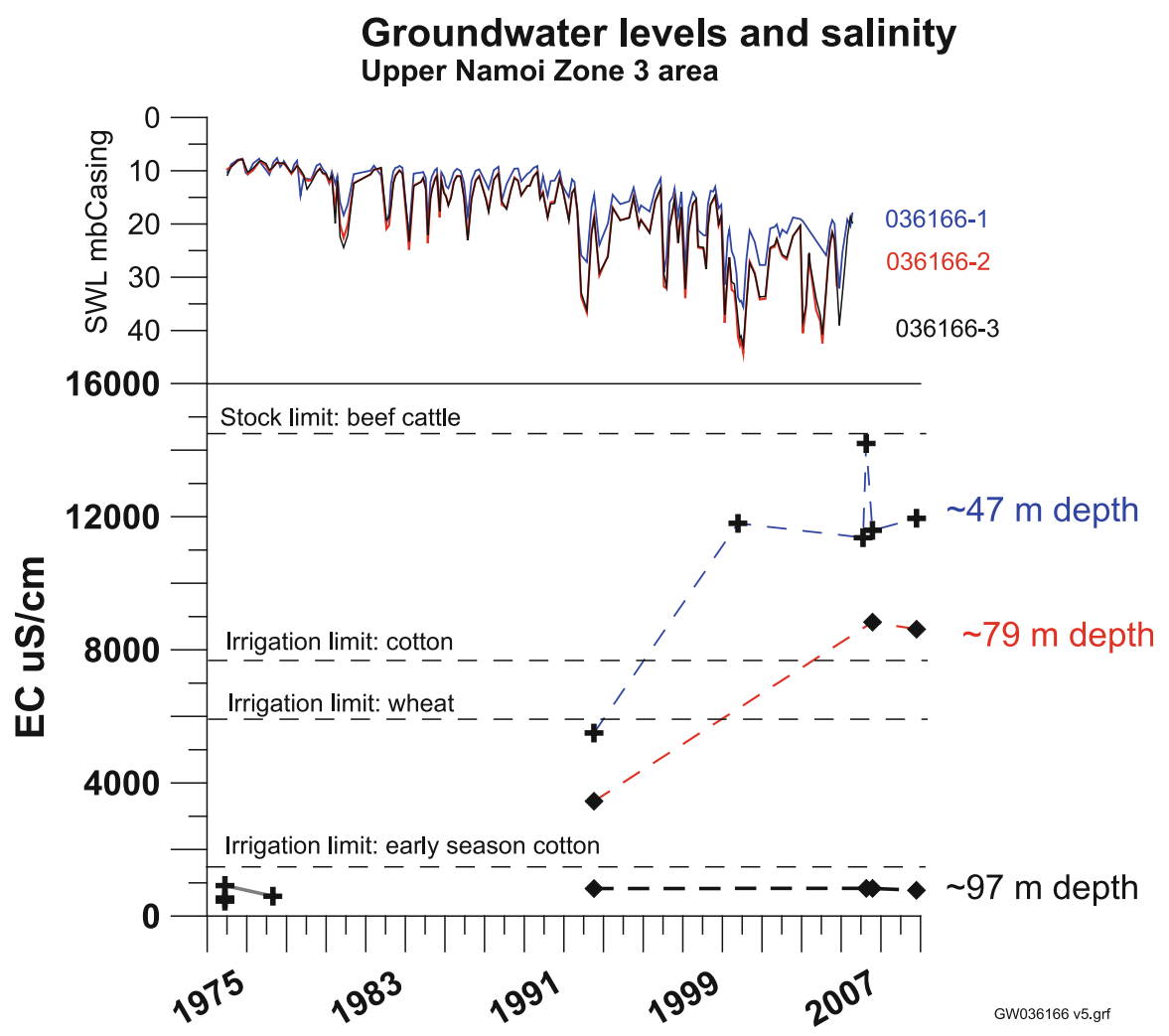

Fig. 15.16 Groundwater level and salinity changes over time compared to beneficial use guidelines at site GW036166 (After Timms et al. 2009)

Measuring and monitoring soil water status should be essential parts of an integrated management program. Irrigation managers and the irrigation service sector now have a large range of equipment available for measuring the soil water status, with favourable cost-benefits, water savings and crop yields. The Cotton industry has developed best management practices for irrigation (CRDC 2008) for irrigators, which includes a protocol for monitoring the salinity of bore water (Timms et al. 2009). Recommendations for management responses include calls for more strategic monitoring, improving data integrity and archiving, understanding of processes and numerical modelling of aquifer salinity changes that could occur in the future (Timms et al. 2009; McLean et al. 2011; Kelly et al. 2013).

Assessing and managing irrigation salinity on a farm by farm basis includes a range of possible investigations, including soil type and EM surveys, water salinity and depth to water table monitoring. Best practice irrigation requires scheduling to match plant water requirements at differing stages of the season and taking into account soil type and salinity. Excess drainage is to be avoided, or reduced, in salt prone areas, or managed with more efficient irrigation methods such as drip and spray application. 
Strategic groundwater monitoring guidelines were developed by Timms et al. (2009) with a 4 level Best Management Practice (BMP) for irrigation bores, and a 3 level guideline for sub-catchment and regional scale. For example, a level $2 \mathrm{BMP}$ for irrigation bores is to maximize crop yields by using bore water within appropriate salinity guidelines.

\section{Regional Level}

At a regional level, the existing State Government Water Sharing Plan has set a sustainable yield (also referred to as the diversion limit) of 86,000 ML per year (NSW 2008; Smithson 2009). Kelly et al. (2013) demonstrated (at the $90 \%$ confidence interval) that under this rate of withdrawal the groundwater level will continue to fall, which is to be expected given that groundwater hydrographs indicate that dynamic equilibrium has not been reached. The sustainable-yield groundwater flow modelling undertaken by CSIRO (2007) indicates that under some climatic scenarios dynamic equilibrium will not be reached within at least 100 years. Thus, the current Namoi Catchment Action Plan 2010-2020 (NCAP 2010) goal of not allowing the groundwater levels to fall cannot be achieved without reducing groundwater withdrawals, or changing the way both surfacewater and groundwater are distributed and used throughout the whole of the Namoi Catchment. Kelly et al. (2013) argue that if groundwater is allocated and managed only in the context of point of use, or in assumed isolation from surface water, sustainable access to groundwater for all existing irrigation farms will be difficult to attain while minimising the impact on groundwater-dependent ecosystems. This will only be achieved if surface-water and groundwater are managed as a single resource at the catchment scale.

\section{State Level}

The NSW State Groundwater Policy Framework (NSW DLWC 1997) highlights the need to manage the access to groundwater within the sustainable yield of a system so that the availability of the resource is sustained for all consumptive uses as well as the dependent ecological processes. Groundwater quantity, groundwater quality (NSW DLWC 1998) and groundwater dependent ecosystems are specifically addressed in the framework. Status reports are regularly prepared on the basis of monitoring in groundwater management areas and zones. Local groundwater allocations and trading rules are decided on the basis of groundwater level and quality status assessments. Emphasis is placed on addressing hotspot issues and on salinity management in areas where downwards leakage of saline water is occurring due to extraction. For example, Smithson (2009) used saturated thickness depletion limits and water level constraints to define local impact management rules in the Lower Namoi alluvium.

In 2012, the Aquifer Interference Policy (AIP) was introduced to clarify rules for groundwater licencing, with particular implications for coal bed methane and mining projects (NSW 2012). The AIP covers activities that interfere with an aquifer including penetration, obstructing flow, taking or disposing of water. The AIP also includes considerations for dewatering for infrastructure and injection of waste into 
groundwater systems for both individual and cumulative impacts. The assessment criteria are called 'minimal impact considerations' and include impacts on water table levels, water pressure levels and water quality in different types of groundwater systems.

The state Office of Water (NOW), a stand-alone regulator, has responsibility for regulation under the Water Act 1912 (NSW) which is gradually being superseded by the Water Management Act 2000 (NSW) (WMA 2000). Holley and Sinclair (2012) reviewed compliance and enforcement of water licences in NSW and deduced that over 24,000 surface and groundwater licences were covered under the WMA, accounting for $95 \%$ of all water extracted in NSW. The WMA 2000 details a range of breaches with potential application to groundwater, including taking water that is not authorised by a licence, constructing a bore without approval, not maintaining a water meter and interfering with an aquifer.

\subsection{Integration and Conclusions}

Given the increased dependence of groundwater globally to maintain societies and their economies, it is critical to combat the various types of degradation threatening groundwater supplies. This chapter has looked at the issue of groundwater salinization, one of the major forms of aquifer degradation, from a theoretical and practical view.

Assessment of the physical and chemical processes causing salinization of the rootzone and shallow aquifers identified three major types of salinity based on soil and groundwater processes: (i) groundwater associated salinity, (ii) transient salinity and (iii) irrigation induced salinity (Rengasamy 2006). These types of salinity all result in accumulation salt stores in the root zone which can have major effects on plant growth and soil processes. The salt stores can also affect groundwater supplies deeper in the landscape. Three processes were specifically recognised as causing salinization of aquifers: (i) rising groundwater tables due to inefficient surface irrigation and inadequate drainage, (ii) natural salinity mobilized from the landscape due to land clearing of native vegetation, and (iii) disturbance of natural groundwater salinity stratification by well construction and groundwater extraction (Foster and Chilton 2003).

The extent of the salinization problem, including the influence of management and policy, was explored using two case studies representative of a developing country (Pakistan) and developed country (Australia).

The Indus Valley (Pakistan) case study highlighted deep percolation from the irrigation system of canals and lack of drainage that resulted in a major imbalance in the amount of salt entering and leaving the soils and hence salt accumulation in the shallow soils. A cost benefit analysis of implementing three management strategies (no intervention, an engineering approach, and an agronomic approach) on four land categories was carried out. The four land categories ranged from extremely degraded land through to normal land and were based on the severity of waterlogging (depth of water table) and the soil salinity. The Net Present Values (NPV) of the three strategies on the four land categories were compared over a period of 25 years, using a discount rate of $6 \%$. The results indicated that some 
strategies can maintain farm profitability in the long run, provided that the right kind of treatment is given to the right type of land at the right time.

The Namoi catchment (Australia) study demonstrated that aquifer salinization occurs from salt remobilisation in the landscape, with redistribution by changing groundwater flows. The source of salt for shallow aquifers that are located inland, far from possible sea-water intrusion, includes salt naturally accumulating in the soil, or leakage from saline aquifers located overlying, adjacent to, or below freshwater aquifers. A detailed monitoring program indicated that both salinization and freshening processes occurred in aquifers at different depths. The most significant aquifer salinization processes in this area include: (i) leaching of saline soils with increased recharge; (ii) downwards and lateral flow of shallow saline groundwater into deeper fresh aquifers as hydraulic gradients are enhanced by extraction of deep fresh alluvial aquifers for irrigation, and (iii) possible leakage that occurs at some locations via aging and poorly constructed bores.

Both the case studies from the Indus Valley and the Namoi Catchment involved examples of how management strategies and policy can be integrated to reduce salinization of the root zone and aquifers respectively. Thus:

(i) The Indus Valley case study demonstrated how it is now feasible for planners to make informed decisions on the rehabilitation of salinized surface soil. Previously, investments in salinity had not provided economic returns. Therefore, despite great interest, funding agencies had little confidence in making investments for salinity management. The approach taken in this case study linked viable policy management that has economic credibility to welldocumented, and practical, salinity management.

(ii) In the Namoi case study, management responses to groundwater quality issues require both local initiatives and regional efforts to understand and raise awareness and inform state-based regulatory approaches. These approaches include policy and compliance functions consistent with Murray-Darling Basin Authority and National water reforms (Holley and Sinclair 2012).

In summary this chapter on root zone and groundwater salinization processes has indicated that as the surface root zone can be a major source of salts that lead to aquifer salinization, it is critical that both the interactions within and between these zones (i.e. root zone and aquifers) are understood if salinization of valuable groundwater supplies is to be prevented.

It is important to note that this chapter has focussed on the biophysical processes in the root zone and aquifers and their interactions that are likely to cause groundwater salinization. As demonstrated by the two case studies, management strategies to reduce salinity both in the root zone and/or in aquifers, also need to be carefully integrated with policy. Such integration needs to consider the following:

(i) Land use policies to reduce salinity need to take into account the suitability of the soil and the type of crop;

(ii) The nature of local and regional water allocation policies need to be integrated; 
(iii) Agricultural and agronomic policies that encourage groundwater use in salinity affected areas can accelerate the processes of aquifer salinization.

(iv) There is a need to understand and closely monitor catchment scale processes and their feedback on each other for sustainability of land and water resources. Related to land and aquifer salinization such catchment scale processes may include the clearing of deep rooted native vegetation for agricultural extension, over extraction of groundwater, and the use of saline and sodic water for irrigation. The feedbacks from each of these processes can accelerate land and aquifer salinization.

(v) It is important not to degrade the resources (land and water) in the first place as some processes such as soil salinization and aquifer degradation can be non-reversible.

(vi) Integrated catchment management is urgently required.

Other chapters in this book deal in more detail with the issue of how to integrate management strategies to reduce salinity with policy, e.g. Chap. 2.

Acknowledgements The assistance of Clive Hilliker with the illustrations is gratefully acknowledged.

Open Access This chapter is distributed under the terms of the Creative Commons AttributionNoncommercial 2.5 License (http://creativecommons.org/licenses/by-nc/2.5/) which permits any noncommercial use, distribution, and reproduction in any medium, provided the original author(s) and source are credited.

The images or other third party material in this chapter are included in the work's Creative Commons license, unless indicated otherwise in the credit line; if such material is not included in the work's Creative Commons license and the respective action is not permitted by statutory regulation, users will need to obtain permission from the license holder to duplicate, adapt or reproduce the material.

\section{References}

Abbs K, Littleboy M (1998) Recharge estimation for the liverpool plains. Aust J Soil Res 36:335-357

ADWG (2008) The Australian drinking water guidelines, Water quality protection note, Department of Water, Government of WA

Andersen MS, Acworth RI (2009) Stream-aquifer interactions in the Maules Creek catchment, Namoi Valley, New South Wales, Australia. Hydrogeol J 17(8):2005-2021

ANZEEC (2000) Australian and New Zealand guidelines for fresh and marine water quality, vol 1. Australian and New Zealand Environment and Conservation Council, Canberra

Arshad M (2007) Improving investment decisions for rehabilitation of salt-affected lands: a case study from the wheat-cotton zone of Pakistan. Major research essay (unpublished), Australian National University

Aslam M, Prathapar SA (2006) Strategies to mitigate secondary salinisation in the Indus basin of Pakistan: a selective review, vol 97, IWMI research report. International Water Management Institute, Colombo 
Badenhop AM, Timms WA (2012) Long-term salinity changes in an Inland Aquifer, NSW, Australia. Paper presented at the 34th hydrology \& water resources symposium, Sydney, 19-22 Nov 2012

Barrett C, Williams RM, Sinclair P (2006) Groundwater chemistry changes due to mixing - Lower Namoi Valley, New South Wales. Paper presented at the Murray Daling Basin Groundwater conference, Canberra, ACT

Blackburn G, McLeod S (1983) Salinity of atmospheric precipitation in the Murray - Darling Drainage Division, Australia. Aust J Soil Res 21:411-434

Bruvold WH, Daniels JL (1990) Standards for mineral content in drinking water. Am Waterworks Assoc J 82(2):59-65

Charlesworth P (2005) Soil water monitoring. Irrigation insights, vol 1. Land and Water Australia

CRDC (2008) WATERpak - a guide for irrigation management in cotton. Cotton Research and Development Corporation. http://www.cottoncrc.org.au/industry/Publications/Water/WATERpak/ WATERpak_Forward_Disclaimer

CSIRO (2007) Water availability in the Namoi. A report to the Australian Government from the CSIRO Murray-Darling Basin sustainable yields project, Canberra, ACT

David K, Prathapar S, Creelman B, Hanckok GR, Voller T (2003) Management of salinity issues for the closure of open cut coal mines. ACARP report $\mathrm{C} 11050$

Foster SSD, Chilton P (2003) Groundwater: the processes and global significance of aquifer degradation. Philos Trans R Soc Lond B 358:1957-1972

Greene RSB, Posner AM, Quirk JP (1973) Factors affecting the formation of quasi-crystals in montmorillonite. Soil Sci Soc Am Proc 31:457-460

Hancock GR, Wright A, De Silva H (2005) Long-term final void salinity prediction for a postmining landscape in the Hunter Valley, New South Wales, Australia. Hydrol Process 19:387-401. doi:10.1002/hyp.5538

Hillel D (2000) Salinity management for sustainable irrigation: integrating science. Environment and Economics, World Bank, IBRD, Washington, DC

Holley C, Sinclair D (2012) Compliance and enforcement of water licences in NSW: limitations in law, policy and institutions. Australas J Nat Res Law Policy 15(2):149-189

International Water Management Institute (IWMI) (2007). IWMI technical reports on salinity management in Pakistan: multiple issues, IWMI, Colombo. Available from: http://www.iwmi. cgiar.org/Publications/Pakistan_Reports/index.aspx\#. Accessed 14 Aug 2007

Kahlown MA, Azam M (2002) Individual and combined effect of waterlogging and salinity on crop yields in the Indus Basin. Irrig Drain 51:329-338

Kelly BFJ, Timms WA, Andersen SM, McCallum AM, Blakers RS, Smith R, Rau GC, Badenhop A, Ludowici K, Ackworth RI (2013) Aquifer heterogeneity and response time: the challenge for groundwater management. Crop Pasture Sci 64:1141-1154

Kelly BFJ, Timms W, Comunian A, McCallum AM, Andersen MS, Acworth RI, Baker A, Blakers RS, Ralph TJ, Giambastiani BMS (2014) A reassessment of the Lower Namoi Catchment aquifer architecture and hydraulic connectivity with reference to climate drivers. Aust J Earth Sci 61:501-511

Khan S, Kordek G (2014) Coal seam gas: produced water and solids. Prepared for the office of the NSW Chief Scientist and Engineer (OCSE). School of Civil and Environmental Engineering, University of New South Wales

Khan ZH, Mohal N, Khan AS (2006) Salinity intrusion, coastal and fluvial flood modelling. Workshop on climate change prediction modelling, Dhaka

Kijne JW (1996) Water and salinity balances for irrigated agriculture in Pakistan, vol 6, IWMI research report. Inernational Water Management Institute, Colombo

Lavitt N (1999) Integrated approach to geology, hydrogeology and hydrogeochemistry in the Lower Mooki River Catchment. Ph.D thesis, University of New South Wales

Marchuk A, Rengasamy P (2011) Clay behaviour in suspension is related to the ionicity of claycation bonds. Appl Clay Sci 53:754-759

Marchuk A, Rengasamy P (2012) Threshold electrolyte concentration and dispersive potential in relation to CROSS in dispersive soils. Soil Res 50:473-481 
Marchuk A, Rengasamy P, McNeil A (2013) Influence of organic matter, clay mineralogy and pH on the effects of CROSS on soil structure is related to the zeta potential of the dispersed clay. Soil Res 51:34-40

Martinez-Beltran J, Manzur CL (2005) Overview of salinity problems in the world and FAO strategies to address the problem. In: Proceedings of the International Salinity Forum, Riverside, pp 311-313

MCA (2012) Water accounting framework for the minerals industry. Minerals Council of Australia, Forrest, ACT

McCallum A, Andersen M, Rau GC, Larsen J, Acworth I (2014) River-aquifer interactions in a semi-arid environment investigated using point and reach measurements. Water Resour Res 50:2815-2829

McLean W, Brown S, Scarff S, Rochford L (2011) Characterisation of hydrogeochemistry and risks to groundwater quality - impact of groundwater pumping on groundwater quality. National Water Commission - Raising National Water Standards Programme, report by Parsons Brinkerhoff to NSW Office of Water

Munns R, Tester M (2008) Mechanisms of salinity tolerance. Annu Rev Plant Biol 59:651-681

NCAP (2010) Namoi Catchment Action Plan 2010-2020. Namoi Catchment Management Authority of New South Wales Government, Gunnedah, NSW

NRC (2010) Management and effects of coalbed methane produced water in the western United States. National Research Council, Washington, DC

NSW (2008) Water sharing plan for the upper and lower Namoi Groundwater Sources NSW legislation. New South Wales Government, Sydney

NSW (2012) NSW Aquifer Interference Policy (2012), Department of Primary Industries, Office of Water, Parramatta

NSW DLWC (1997) The NSW state groundwater policy framework document: NSW department of land and water conservation, Sydney

NSW DLWC (1998) Groundwater quality protection policy: NSW department of land and water conservation, Sydney

NUDLC (2012) Minimum construction guidelines for water bores. National Uniform Drillers Licensing Committee (NUDLC). http://adia.com.au/wp-content/pdf/MCR3RD2012B.pdf

NWC (2012) An assessment of groundwater management and monitoring costs in Australia. Waterlines report, Sinclair Knight Merz for the National Water Commission, Canberra

OGIA (2012) Office of groundwater impact assessment, Underground water impact report for the Surat cumulative management area. Queensland Water Commission

Pakistan Agriculture Research Council (2002) National action programme to combat desertification in Pakistan. Ministry of Environment Government of Pakistan and United Nations Environment Programme UNEP (ESCAP), Islamabad

Quirk JP, Schofield RK (1955) The effect of electrolyte concentration on soil permeability. J Soil Res 6:163-178

Rengasamy P (2006) World salinization with emphasis on Australia. J Exp Bot 57:1017-1023

Rengasamy P (2013) Salt-affected soils: sustainable agriculture. In: Jorgensen SE (ed) Encyclopedia of environmental management. Taylor and Francis, New York, pp 2349-2356

Rengasamy P, Marchuk A (2011) Cation ratio of soil structural stability (CROSS). Soil Res 49:280-285

Rengasamy P, Sumner ME (1998) Processes involved in sodic behaviour. In: Sumner ME, Naidu R (eds) Sodic soils: distribution, properties, management, and environmental consequences. Oxford University Press, New York, pp 35-50

Rengasamy P, Greene RSB, Ford GW, Mehanni AH (1984) Identification of dispersive behaviour and the management of red-brown earths. Aust J Soil Res 22:413-431

Ringrose-Voase AJ, Young RR, Paydar Z, Huth NI, Bernardi AL, Cresswell HP, Keating BA, Scott JF, Stauffacher M, Banks RG, Holland JF, Johnston RM, Green TW, Gregory LJ, Daniells I, Farquharson R, Drinkwater RJ, Heidenreich S, Donaldson S (2003) Deep drainage under different land uses in the Liverpool Plains catchment. Report 3, Agricultural resource management report series. NSW Agriculture, Tamworth, NSW 
Santi PM, McCray JE, Martens JL (2006) Investigating cross-contamination of aquifers. Hydrogeol J 14:51-68

Sarwari A, Bastiaansseni WGM, Bores M, Van Dam JC (2000) Evaluating drainage design parameters for the fourth drainage project Pakistan using SWAP model part I calibration. Irrig Drain Syst 14:257-280

Selman M, Greenhalgh S, Branosky E, Jones C, Guiling J (2009) Water quality trading programs. An International Overview, Washington, DC

Shenhua Watermark (2013) Watermark coal project environment impact statement. NSW Planning and Environment, Sydney, NSW

Shiga Y, Greene RSB, Scott KM, Stelcer E (2011) Recognising terrestrially- derived salt $(\mathrm{NaCl})$ in SE Australian dust. Aeolian Res 2:215-220

Smithson A (2009) Lower Namoi groundwater source: groundwater management area 001 groundwater status report - 2008. NSW Department of Water and Energy, Sydney

Timms WA (2001) The importance of aquitard windows in development of alluvial groundwater systems: lower Murrumbidgee, Australia. Ph.D thesis, University of New South Wales, School of Civil and Environmental Engineering, Kensington, NSW

Timms WA, Acworth RI (2002) Induced leakage due to groundwater pumping and flood irrigation at the Pullaming Agricultural Field Station, vol 208, Liverpool Plains research report. University of New South Wales Water Research Laboratory, Manly Vale, NSW

Timms WA, Ackworth RI (2009) Quantifying the potential impact of leaky boreholes. In Proceedings groundwater in the Sydney basin symposium, International Association of Hydrogeologists NSW Branch, Sydney, 4-5 Aug 2009

Timms W, Bourke S (2014) Tackling the complexities of mine dewatering. Queensland Mining and Energy Bulletin Autumn (20)

Timms WA, Badenhop A, Rayner D, Mehrabi S (2009) Namoi groundwater monitoring and evaluation. Report no. 2. Part A: results of 2009 groundwater monitoring and recommendations for future best practice monitoring framework. Part B: groundwater user survey. Technical report 2009/25. UNSW Water Research Laboratory, Manly Vale, NSW

Timms W, Young R, Huth N (2012) Implications of deep drainage through saline clay for groundwater recharge and sustainable cropping in a semi-arid catchment, Australia. Hydrol Earth Syst Sci 16:1203-1219

Turner ML, Greene RSB, Knackstedt M, Senden TJ, Sakellariou A, White I (2008) Use of gamma emission CT to study the effect of electrolyte concentration on regions of preferred flow and hydraulic conductivity in deep regolith materials. Aust J Soil Res 46:101-111

Vink S, Hoey D, Robbins S, Roux E (2013) Regulating mine water releases using water quality trading. In: Wolkersdorfer Ch, Brown A, Figueroa L (eds) Reliable mine water technology, Golden, CO. International Mine Water Association (IMWA), Wendelstein, Germany, pp 71-76

Werner AD, Bakkerk M, Post VEA, Vandenbohedec A, Lua C, Ataie-Ashtiani B, Simmons CT, Barry DA (2013) Seawater intrusion processes, investigation and management: recent advances and future challenges. Adv Water Resour 51:3-26

Williams J, Stubbs T, Milligan A (2012) An analysis of coal seam gas production and natural resource management in Australia. A report prepared for the Australian Council of Environmental Deans and Directors by John Williams Scientific Services Pty Ltd, Canberra, Australia

WMA (2000) Water Management Act. NSW Government legislation. http://www.legislation.nsw. gov.au/xref/inforce/?xref=Type\%3Dact\%20AND\%20Year\%3D2000\%20AND\%20no\%3D92\& nohits $=\mathrm{y}$

Wong VNL, Johnston SG, Burton FD, Hirst P, Sullivan LA, Bush RT, Blackford M (2015) Seawater inundation of coastal floodplain sediments: short-term changes in surface water and sediment geochemistry. Chem Geol 398:32-45

Yeboah NNN, Burns SE (2011) Geological disposal of energy-related waste KSCE. J Civ Eng 15 (4):697-705. doi:10.1007/s12205-011-0010-x 